\title{
Analysis of Air Pollution Migration during COVID-19 Lockdown in Krakow, Poland
}

\section{Aerosol and Air Quality Research}

Special Issue:

Special Issue on Air Quality in a Changed World: Regional, Ambient, and Indoor Air Concentrations from the COVID to Post-COVID Era (III)

\section{OPEN ACCESS}

Received: October 11, 2021 Revised: December 20, 2021 Accepted: January 31, 2022

\section{${ }^{*}$ Corresponding Author: \\ Zareba@agh.edu.pl}

\section{Publisher:}

Taiwan Association for Aerosol Research

ISSN: $1680-8584$ print

ISSN: 2071-1409 online

(c) Copyright: The Author(s). This is an open access article distributed under the terms of the Creative Commons Attribution License (CC BY 4.0), which permits unrestricted use, distribution, and reproduction in any medium, provided the original author and source are cited.

\section{Mateusz Zaręba*, Tomasz Danek}

Department of Geoinformatics and Applied Computer Science, Faculty of Geology, Geophysics and Environmental Protection, AGH University of Science and Technology, 30-059 Krakow, Poland

\section{ABSTRACT}

The historical analysis of particulate matter (PM) concentration proved that pro-clean-air legislation and grassroots movement have a positive impact on air quality in Krakow. However, when the temperature drops in late autumn, winter, and early spring, the problem of smog still occurs in the city. In a 24-hours averaging period, the concentration of $\mathrm{PM}_{10}$ has exceeded EU norms in 10 days in pandemic March 2021. It is estimated that $50 \%$ of the carbon fraction in $\mathrm{PM}_{10}$ measured in Krakow comes from domestic heating. This is mostly caused by the migration of air pollutants from neighboring municipalities (where the use of fossil fuels for heating is allowed) to Krakow (where this type of households heating is forbidden). In this paper, we analyzed $\mathrm{PM}_{10}$ concentrations in Krakow and neighboring municipalities. Moreover, we showed the main migration directions of air pollutants in connection with wind direction. We used statistical analysis to examine the relations between $\mathrm{PM}_{10}$ concentrations and other physical characteristics of the atmosphere. It includes measurements of pressure, temperature, and humidity. We were collecting data during early spring 2021 when car transportation was limited due to the COVID-19 lockdown in Poland. Car transportation in Krakow is responsible for up to $20 \%$ of the $\mathrm{PM}_{10}$ carbon fraction concentration. It allowed for observation of air pollutions from solid fuel heating with minimum traffic-generated pollution background. The Airly@ low-cost sensors (LCS) network was used for this study.

Keywords: Air quality monitoring, LCS, Air pollution measurements, Particulate matter, Fossil fuels heating

\section{INTRODUCTION}

The problem of air pollution in Krakow has a long history. In the 1970s and 1980s, industry, mainly metallurgy, was one of the main air pollution factors. Over the years, as the population increased, the role of this factor decreased in favor of low emissions from fossil fuels heating and transportation (Bokwa, 2007). Krakow city's geographical location is well described in the literature (Morawska-Horawska and Lewik, 2003; Bokwa, 2019), as well as its geological structure (Rutkowski, 1989). The city itself cannot be considered in an isolation from the mesoscale landform features of the region. The general geographic information and urbanization relationships are described in the official Malopolska region strategy document (Urbanowicz et al., 2020) while the information about the near-surface geological structure has been the subject of many studies (Foldvary, 1998; Zaręba et al., 2020). Krakow is located in the valley. From the north, the elevation gain is related to Polish Jurassic Highland, on the south with limestone outcrops and Wielickie foothills. In a more mesoscale approach, going further south, there is the Carpathian inner-mountain basin and the Carpathian Mountains are just 100 km away (Gradziński, 1972). On the west Krakow borders with fault-block hills of Krakow Gate and Oswiecim basin, and from the west with Sandomierz lowland basin. The main river flowing through the city from west to east is the Vistula River (Hrehorowicz-Gaber, 2015). The latest research shows that thanks to pro-clean-air legislation, 
the average PMs concentration in the city of Krakow has been systematically decreasing since 2011. Reduced car traffic during the COVID-19 pandemic allowed us to observe the influx of pollutants from fossil fuels heating to the city of Krakow from nearby towns. The Municipal Traffic Engineer Department research clearly shows that at the biggest city intersection during the COVID-19 pandemic period were on average 40\% fewer cars compared to the pre-pandemic year 2019 (The Municipal Traffic Engineer Department, 2020). According to the Central Statistical Office of Poland's official data, every fifth inhabitant of large provincial cities (including Krakow) changed their work to remote work during the pandemic in 2021 (Statistics Poland, 2021b). The most remote work was performed by employees of the following industries: IT and communication (57\%), financial and insurance (30\%), employees of universities (30\%) (European Commission, 2021). Krakow's universities conducted remote learning throughout the entire period of the pandemic (Kołodziej, 2021). The period of the pandemic in Poland can be divided into several stages, which are characterized by a total lockdown, a partial lockdown (with elements of sanitary restrictions easing), and periods without sanitary obstacles. The first case of coronavirus in Poland was diagnosed on $4^{\text {th }}$ March 2020 (Raciborski et al., 2020). The most severe lockdown was the first one introduced on $24^{\text {th }}$ March 2020, in which domestic movements for people in Poland were prohibited, except for commuting to the necessary workplaces, grocery shops, hospitals, and pharmacies. The prohibition of access to forests, beaches, or parks was announced as well (Szumowski, 2020). Limiting the restrictions was divided into 4 stages (Serwis Rzeczypospolitej Polskiej, 2020). In the fall, restrictions resumed, but the lockdown was less severe than that announced in March. Until $25^{\text {th }}$ March 2021, full-time education in special schools and the first grades of primary school was allowed. In the other cases, there was a requirement for remote learning. Gyms, sports clubs, spas, cinemas were closed and shopping malls were partially open with a significant reduction in the number of visitors. The restaurants served take-out only. There was a strict obligation to observe the sanitary regime and social distance (Morawiecki, 2021a). As of $25^{\text {th }}$ March 2021, the lockdown rules were tightened. All educational institutions, nurseries, shopping malls, and hotels have been closed (Morawiecki, 2021b). On $19^{\text {th }}$ April 2021, the lockdown ended and the restrictions were gradually loosened (Serwis Rzeczypospolitej Polskiej, 2021).

Many studies show that overexposure to PMs may be the main factor in the development of many disease entities. This includes problems with the respiratory and circulatory systems (Dai et al., 2014), the occurrence of certain types of cancer (Raaschou-Nielsen et al., 2013), and even problems with procreation (Pedersen et al., 2013). Apart from the diseases presented above, the influence of PMs on the development of neurological diseases cannot be omitted. Relatively new research in this area shows the impact of PMs pollution on the development of diseases such as Alzheimer's or Parkinson's (Thurston et al., 2017). Bokwa (2008) showed that long-term exposure to air pollution has a very negative impact on the health problems of Krakow habitants. There are also similar conclusions from a recent study done by Traczyk and Gruszecka-Kosowska (2020).

In Poland, air pollution monitoring is carried out under European Union directives and law. The main document on which the current air pollution law is based is directive 2008/50/EC (in law 21 May 2008). This directive uses the acronym AAQD - Ambient Air Quality and cleaner air for Europe Directive (European Parliament, 2008). There are over 4300 air pollution reference monitoring stations $\left(\mathrm{PM}_{10}\right.$ and $\left.\mathrm{PM}_{2.5}\right)$ in the EU, including 288 in Poland. Krakow city is located in zone PL1201 with only a few measurement stations of $\mathrm{PM}_{10}$ and $\mathrm{PM}_{2.5}$ - three automatic for both $\mathrm{PM}_{10}$ and $\mathrm{PM}_{2.5}$, two manual for $\mathrm{PM}_{10}$, and only one manual measurement for $\mathrm{PM}_{2.5}$. Based on the EU legislation, the Polish legislator introduced the standards for PMs concentration $\left(25 \mu \mathrm{g} \mathrm{m}^{-3}\right.$ for 1-year averaging for $\mathrm{PM}_{2.5}, 50 \mu \mathrm{g} \mathrm{m}^{-3}$ for 24-hour averaging for $\mathrm{PM}_{10}$ ) and their measurements as well. For gravimetric manual measurements it is norm PN-EN 12341, and for automatic measurements norm PN-EN 16450 (Chief Inspectorate for Environmental Protection, 2021).

Reference stations allow for very detailed measurements with high accuracy, however, their rare number is not enough for geospatial analysis or pattern investigation. For this purpose, lowcost sensors (LCS) can be used, however, currently, the EU does not allow measurements from these sensors for reporting. The reason is that measurements from LCS can be affected by many different factors - mostly weather-related like humidity. On the other hand, the EU stands that in many cases, LCS gives comparable results with reference stations (Gerboles et al., 2017). There are a few groups of LCS based on physical and chemical characterization. The most popular sensors in Krakow are Airly optical sensors (https://map.airly.org/). The use of local geospatial 
analysis methods and dedicated solutions allows for a much better understanding of many phenomena (Briggs et al., 2010; Hysenaj, 2016; Zaręba et al., 2019; Lupa et al., 2020). Based on previous research, Airly LCS accuracy in this period was very similar to the reference station measurements and this allows them to be used for geospatial analysis. It is important to know that LCS sensors need to be corrected according to the reference station measurements and weather-related conditions to provide reliable measurements of PM concentrations. On the other hand, the uncertainties of their measurements are greater than those of traditional measurements at reference stations, and their determination is more complicated (Peltier et al., 2021). Each Airly sensor is dynamically calibrated using factors generated by artificial intelligence (AI) and machine learning (ML) algorithms based on the specific characteristics of the particular location. Data that are available through their API for public use are already corrected according to the factors mentioned before. Airly is not sharing its calibration algorithms with the public (Airly, 2021b). However, the use of ML techniques for this purpose is well established and has been published in many papers (Zimmerman et al., 2018; Okafor et al., 2020; Wang et al., 2020), as well as discussed in the official World Health Organisation and World Meteorological Organization report (Peltier et al., 2021). It was also shown that during the COVID-19 pandemic spring the migration of air pollutions from solid fuels heating from surrounding municipalities to Krakow was the main source of PMs in the city as transportation was significantly reduced due to lockdown. Research made by scientists from AGH, commissioned by Krakowski Holding Komunalny (KHK) SA in Krakow, with the substantive support of the Voivodeship Inspectorate for Environmental Protection (WIOŚ) and the Chief Inspectorate for Environmental Protection (GIOŚ) and the financial participation of the Air Quality Department of the Municipal Office of Krakow and companies from the Miejskie Przedsiębiorstwo Energetyki Cieplnej SA and Miejskie Przedsiębiorstwo Komunikacyjne SA, showed that almost $50 \%$ of $\mathrm{PM}_{10}$ consist of carbon fraction, $20 \%$ are inorganic secondary aerosols, the remaining ions are about $10 \%, 3-4 \%$ are metals, and the rest are unidentified components. Detailed studies of the isotopic composition of carbon proved that a major part of that fraction is coal. Its share and sources turned out to be varied due to the period of the year - from solid fuel heating - during autumn-winter-early spring period it is about $50 \%$, while in the rest of the year it is about $20 \%$. The share of transport traffic varied depending on the location and year period. During summer it was $32-42 \%$, while during winter it was about 11-22\%. The biogenic fraction part of carbon (natural emissions and biomass combustion) remains constant at around 30\% (Voivodship Sanitary Inspectorate, 2020). Report of the National Center for Emission Management and Balancing, Institute of Environmental Protection - National Research Institute shows that $50 \%$ of emission sources of $\mathrm{PM}_{10}$ and $\mathrm{PM}_{2.5}$ in Krakow are related to non-industry solid fuel heating, $9 \%$ of sources are manufacturing processes, $10 \%$ are related with industry combustion process while agriculture is the source of only $4.6 \%$ of $\mathrm{PM}_{10}$ pollution (Institute of Environmental Protection - National Research Institute, 2019). In our previous study including observations from the last 10 years, we showed also that pro-clean-air legislation in Krakow and grassroots movements helped to decrease average PM concentration in the city prohibiting the use of solid fuels heating. We also demonstrated the relation between relative comfort zone temperature (Jendritzky et al., 2001) and the level of $\mathrm{PM}_{10}$ concentration from solid fuel heating in neighboring municipalities. We have shown that the feeling of cold determined based on the temperature measured by particular sensors at a given hour is a factor that allows identifying sources of pollution from solid fuels heating. For this purpose, we used spatial-temporal analysis of temperature and PMs concentration together with kernel density estimate of PMs and temperature concerning Predicted Mean Vote (PMV) and Perceived Temperature (PT) indicators (Jendritzky et al., 2001). We have indicated the places that were the main sources of air pollution transported to Krakow by diffusion during the spring lockdown in Poland (Danek and Zaręba, 2021).

In this study, our goal was to investigate the main sources of PMs pollution in accordance with wind direction and geographical location using a dense grid of Airly LCS. We wanted to examine the impact of particular towns and villages surrounding the city of Krakow not in a general way but with the use of categorization. According to Statistics Poland, Krakow has over 700,000 inhabitants while the number in the whole Krakow agglomeration (Krakow and surrounding municipalities) is close to 1.5 million (Statistics Poland, 2021a). Our goal was also to check whether there is not only spatial but also temporary evidence that pollutants emitted in neighboring municipalities are finally transmitted to the city of Krakow. The presented paper shows the unique use of a 
dense LCS grid for pollution migration during the COVID-19 pandemic period in a very specific region of Europe. Despite the very restricted air protection law, Krakow is still one of the most polluted cities in the world (Rogala, 2021).

\section{METHODS}

The experiments were conducted using a quasi-regular, dense grid of 90 Airly optical LCS (data available from: https://map.airly.org/, accessed on 28 September 2021). The free license of Airly allows for the use of no more than 100 sensors through their API. Sensors provided measurements of $\mathrm{PM}_{1}, \mathrm{PM}_{2.5}$, and $\mathrm{PM}_{10}$ concentration, pressure, temperature, and humidity. Based on correlation analysis between $\mathrm{PM}_{1}, \mathrm{PM}_{2.5}$, and $\mathrm{PM}_{10}$ (see Table 1 ) we decided to use in this study only $\mathrm{PM}_{10}$ measurements as a good representative of air pollutions from solid fuel heating with a correlation coefficient with $\mathrm{PM}_{2.5}$ equals 0.997 and with $\mathrm{PM}_{1}$ equals 0.996 . The comparison was made based on Airly LCS averaged measurements in March. There are also other motives for which the $\mathrm{PM}_{10}$ fraction was selected for further analysis. EU standards for $\mathrm{PM}_{10}$ concentration are significantly higher than for $\mathrm{PM}_{2.5}$, thus it is better to choose $\mathrm{PM}_{10}$ while considering LCS as the accuracy for $\mathrm{PM}_{10}$ measurement is about $20 \%$ of EU norm, while for $\mathrm{PM}_{2.5}$ it is $50 \%$. Another thing is that many reports and research done in the past were conducted on $\mathrm{PM}_{10}$ concentration or $\mathrm{PM}_{10}$ fraction analysis. It is also important that the $\mathrm{PM}_{10}$ fraction contains information on all particles smaller than 10 microns including particles smaller than 2 microns. In light of these facts, it is reasonable to choose the $\mathrm{PM}_{10}$ as a representative for further analysis. Because Airly sensors can be used by everyone who wants to buy them, the physical coverage of sensors' location in Krakow and neighboring cities is not regular. To provide the quasi-regular grid the custom algorithm in $\mathrm{R}$ was written. The k-nearest-neighbors method was used to find the sensors closest to the 100 point grid (in $\mathrm{X}$ and $\mathrm{Y}$ directions) and then the criterion of the quarter of the distance between particular sensors and grid points was used to decide if the sensors should be included or excluded. Data were collected hourly between $3^{\text {rd }}$ March 2021 and $16^{\text {th }}$ April 2021. The legibility of the PM measurements was proved by the time-series analysis of the government station and the Airly LCS (Danek and Zaręba, 2021). Manufacturer guarantee accuracy of Airly sensors for $-\mathrm{PM}_{1} 5 \mu \mathrm{g} \mathrm{m}^{-3}$ in the range 0-100 $\mu \mathrm{g} \mathrm{m}^{-3}$ and $10 \mu \mathrm{g} \mathrm{m}^{-3}$ over $100 \mu \mathrm{g} \mathrm{m}^{-3}$; for $\mathrm{PM}_{2.5} 10 \mu \mathrm{g} \mathrm{m}^{-3}$ in the range $0-100 \mu \mathrm{g} \mathrm{m}^{-3}, 10 \%$ for measurements in the range $101-500 \mu \mathrm{g} \mathrm{m}^{-3}$, and $20 \%$ over concentration $500 \mu \mathrm{g} \mathrm{m}^{-3}$; for $\mathrm{PM}_{10}$ accuracy is the same as for $\mathrm{PM}_{2.5}$ (Airly, 2021a). Sensor 36808 located in Niepołomice is the nearest to an official government $\mathrm{PM}_{10}$ station located on 3 May Street in Niepołomice. Airly sensor 36808 measurements were averaged in a 24-hour window and plotted together with the government sensor measurements (see Fig. 1). The correlation coefficient between their measurements in the presented period was high - over 0.93 (Danek and Zaręba, 2021).

This period was chosen as it was the last strict lockdown in Poland. More or less strict lockdown regulations were in force from $8^{\text {th }}$ August 2020 to $24^{\text {th }}$ May 2021 with various changes during this period depending on the number of COVID-19 cases. Due to the rapid increase in infections numbers since the beginning of March, from 25 $5^{\text {th }}$ March 2021 to $19^{\text {th }}$ April 2021, the lockdown was tightened (see in detail in the introduction). Krakow's labor market is dominated by employment in the IT, financial services, and education sectors (European Commission, 2021). It is known from the Central Statistical Office of Poland that most of these workers during the pandemic performed their work remotely without having to travel to their place of work (Statistics Poland, 2021b). Moreover, the number of students is almost $20 \%$ of the inhabitants of Krakow (Dębkowska et al., 2019). In the analyzed period, all of the mentioned above groups worked or learned remotely without generating car traffic. According to the official statement of

Table 1. Correlation coefficients for the PMs values obtained from Airly LCS sensors for the investigated period in March for all data points.

\begin{tabular}{llll}
\hline Concentration $\left(\mu \mathrm{g} \mathrm{m}^{-3}\right)$ & $\mathrm{PM}_{2.5}$ & $\mathrm{PM}_{1}$ & $\mathrm{PM}_{10}$ \\
\hline $\mathrm{PM}_{2.5}$ & 1.000 & 0.998 & 0.997 \\
$\mathrm{PM}_{1}$ & 0.998 & 1.000 & 0.996 \\
$\mathrm{PM}_{10}$ & 0.997 & 0.996 & 1.000 \\
\hline
\end{tabular}




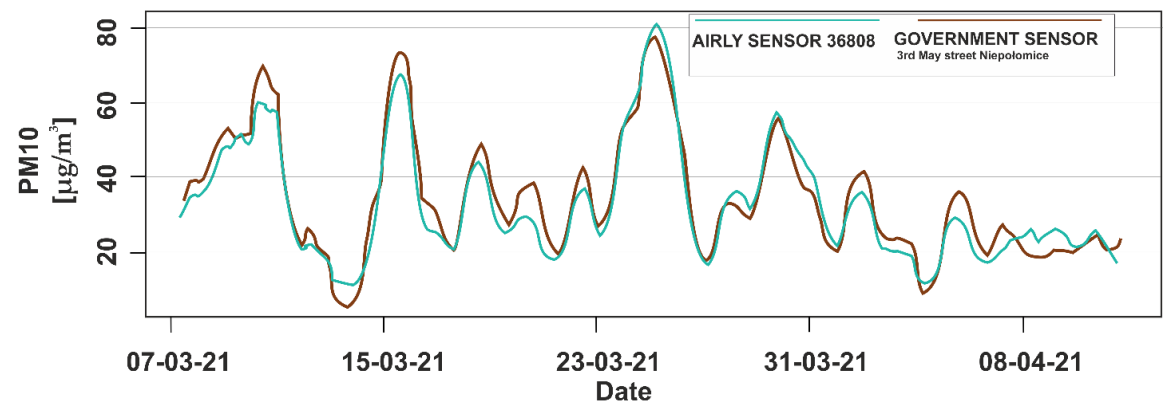

Fig. 1. LCS Airly sensor 36808 (mint) validation according to twenty-four-hour averaged measurements of $\mathrm{PM}_{10}$ from government stations (brown) (Danek and Zareba, 2021 modified).

the General Directorate for National Roads and Motorways, the average number of cars per day across the country decreased by 2,166 vehicles per day in March 2021 compared to March 2019 which is about a $10 \%$ total reduction due to pandemic lockdown (General Directorate for National Roads and Motorways, 2021). In Krakow, the reduction in car traffic was about $40 \%$ (City Traffic Engineer of Krakow, 2020). Additionally, to minimize the impact of car traffic on the analysis of PMs concentration, the hours with the lowest car traffic were selected. Measurements of the traffic volume at the inlets to the city of Krakow, with particular emphasis on transit traffic done by Krakow city, showed that car traffic between hour $10 \mathrm{PM}$ and $6 \mathrm{AM}$ is minimal, while traffic is the greatest between 6 AM-9 AM and 1 PM-6.30 PM (Rosiek, 2017). The main sources of PM pollution in Krakow are low emissions from heating and car traffic (Traczyk, 2020). Selecting the lockdown period and hours in which, under non-pandemic standard conditions, the car traffic drops to almost zero, it made possible to observe pollutants from solid fuels heating only.

To choose days for directional air pollution inflow study the detailed analysis of PM maps was done (created in R using Thin-plane spline (TPS) interpolation method by Nychka et al. (2021)).

According to the WMO report (Peltier et al., 2021), the uncertainties of LCS measurements are higher than those for reference stations. According to the standard, the precision for gravimetric measurements is $2 \mu \mathrm{g} \mathrm{m}^{-3}$ (European Parliament, 2008), while for Airly sensors, the manufacturer declares it at the level of $10 \mu \mathrm{g} \mathrm{m}^{-3}$ for $\mathrm{PM}_{10}$. So it is five times lower. LCSs are sensitive to the influence of atmospheric factors, however, the data provided by Airly is already corrected, and the total uncertainty of individual sensors is not shared. The correlations of indications to the closest reference stations prove the high accuracy of the measurements (Fig. 1). In accordance with the LCS data processing standards specified in the WMO document (Peltier et al., 2021) for Level-4 (Schneider et al., 2019), we made continuous spatial distributions using the TPS method and analyzed the differences between these distributions and the indications of individual sensors. When analyzing a series of maps based on relatively sparse sensors network TPS has two important advantages over kriging. Firstly it does not require semi-variogram fitting thus different maps are directly comparable without any spatial model assumptions. Secondly, the TPS method is very resistant to separated anomalous sensor readings that can occur in sparse networks of LCS due to both measurement errors or the very local character of the observed phenomenon. This effect can be seen in the first map of Fig. 10 (2021-03-15 19:00) in Section 3.3.1 where four extremely high values were observed. The maximum residual value was equal to $184 \mathrm{mg} \mathrm{m}^{-3}$ (Table 2). But as for all these four sensors, the values from neighboring sensors were much lower the anomalies are not observed in the final map. Of course, these separated readings may represent the beginning of pollution emission but their point character makes them impossible for spatial interpretation. Please note that on the other maps such extremes have not been observed (Table 2). It is also worth noting, that increased residuals were observed only in the period when the onset of emission occurs (15-03 19:00 and 16-03 01:00) and not when the maximum pollution levels were recorded. It may indicate that these were not sensor errors but real point observations that have not yet propagated to neighboring sensors. The comprehensive distribution evaluation of PM together with humidity, temperature, and pressure were also performed to study other than wind and geomorphological conditions of PM migration. We used charts and cross-plots taking into account the differentiation by European Air Quality Index. 
Table 2. Summary statistics for estimation errors in sensors network for TPS map models used for geospatial analysis.

\begin{tabular}{llllll}
\hline \multirow{2}{*}{ Map } & \multicolumn{5}{c}{$\mathrm{PM}_{10}$ concentration $\left(\mu \mathrm{g} \mathrm{m}^{-3}\right)$} \\
\cline { 2 - 6 } & Min & $1^{\text {st }}$ quartile & Median & $3^{\text {rd }}$ quartile & Max \\
\hline $15^{\text {th }}$ March 19:00 & -54.17 & -23.67 & -10.99 & 5.98 & 182.43 \\
$16^{\text {th }}$ March 01:00 & -41.41 & -15.04 & -1.59 & 11.23 & 50.09 \\
$16^{\text {th }}$ March 02:00 & -2.50 & -0.68 & -0.18 & 0.70 & 3.02 \\
$16^{\text {th }}$ March 06:00 & -12.52 & -1.97 & -0.20 & 1.75 & 13.42 \\
$18^{\text {th }}$ March 02:00 & -9.89 & -1.95 & -0.47 & 1.24 & 22.40 \\
$18^{\text {th }}$ March 03:00 & -12.01 & -1.95 & -0.31 & 1.74 & 17.86 \\
$18^{\text {th }}$ March 04:00 & -11.17 & -2.84 & 0.08 & 1.84 & 16.19 \\
$18^{\text {th }}$ March 05:00 & -11.71 & -3.00 & -0.08 & 2.54 & 11.65 \\
\hline
\end{tabular}

The lag analysis was performed to study if the time dependency exists between higher emissions of PM in neighboring municipalities and Krakow city. First, the collected dataset was split into data from sensors outside and inside Krakow. Secondly, the sensors outside Krakow were split into groups depending on the main wind direction on a particular day. This allows for the examination of two-time series using the cross-correlation method. This makes it possible to objectively examine if there is a match between the distributions (between sensors group outside and inside the Krakow) and also to see the time difference. During the examined period the main wind direction was west. Only a few days have a dominant north wind direction. There were also days with the very weak wind where the direction was changing from hour to hour. These were classified as no wind days. For the group of sensors outside the Krakow city the following LCS were chosen: group for west wind: 33051 located in Liszki, 8082 Jeziorzany, 37009 Rzozów, 36808 Skawina, 11672 Czernichów, 6163 Stanisław Dolny, 18706 Brzeznica, 11660 Rybna; group for north wind: 31100 Biały Kościół, 492 Brzozówka, 38553 Gotkowice, 313 Skała, 32908 Tomaszowice, 2655 Więckowice (see map in Fig. 2).

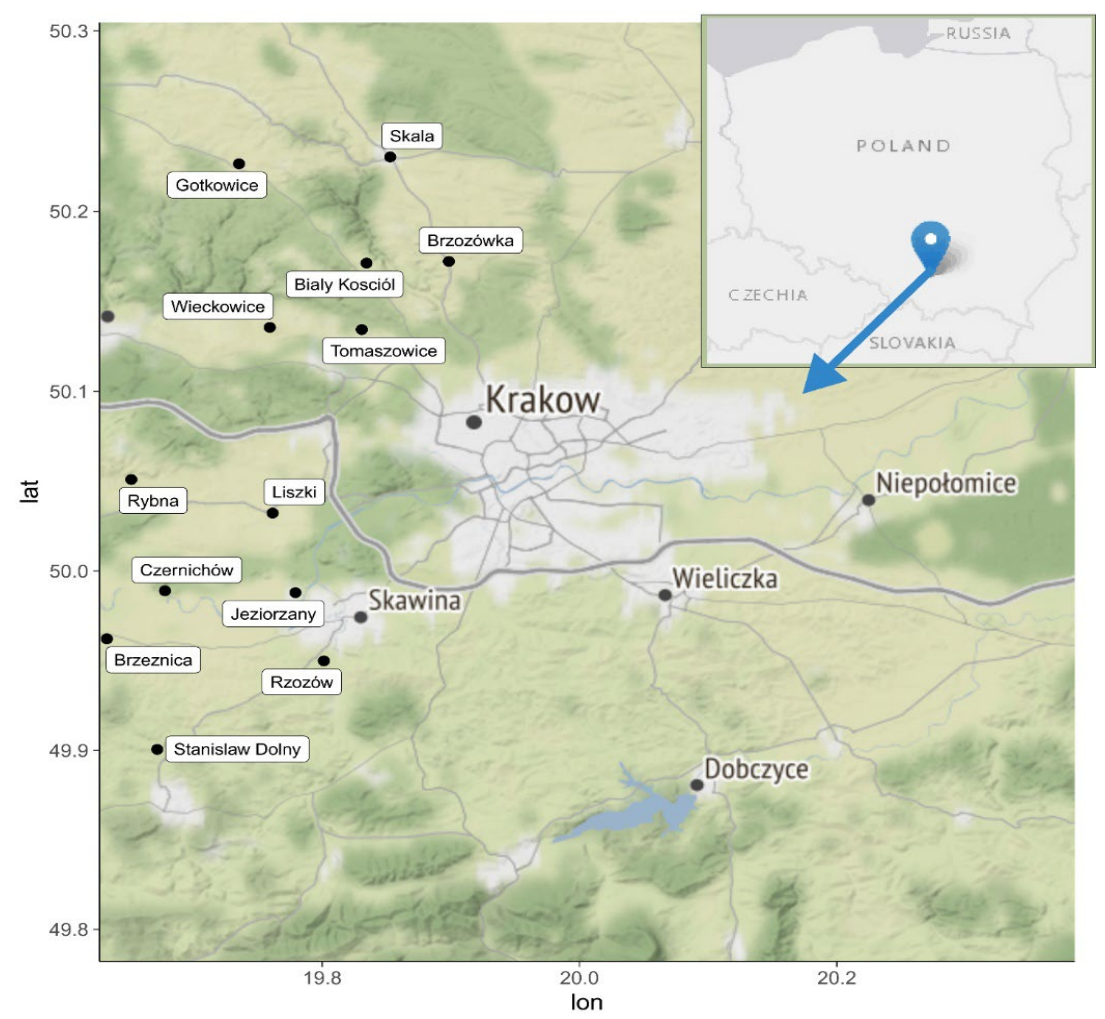

Fig. 2. Krakow and neighboring municipalities map with localization of sensors in west and north group (map sources: ESRI and Stamen). 


\section{RESULTS AND DISCUSSION}

\subsection{Pre-pandemic and Pandemic PM Concentration Analysis}

Without a doubt, the COVID-19 pandemic changed the way we live. Restrictions altered our habits, the way we work, study, and travel. To examine its effect on general $\mathrm{PM}_{10}$ concentration the 24-hour measurement from the official government mass station on Bujaka street in Krakow, from the last 4-years was plotted (see Fig. 3). It can be noticed that in general, the concentration of $\mathrm{PM}_{10}$ in Krakow is decreasing year to year. It is related to law changes and grassroots movements that are present in Krakow since 2011 (Danek and Zareba, 2021). Fig. 4 shows the

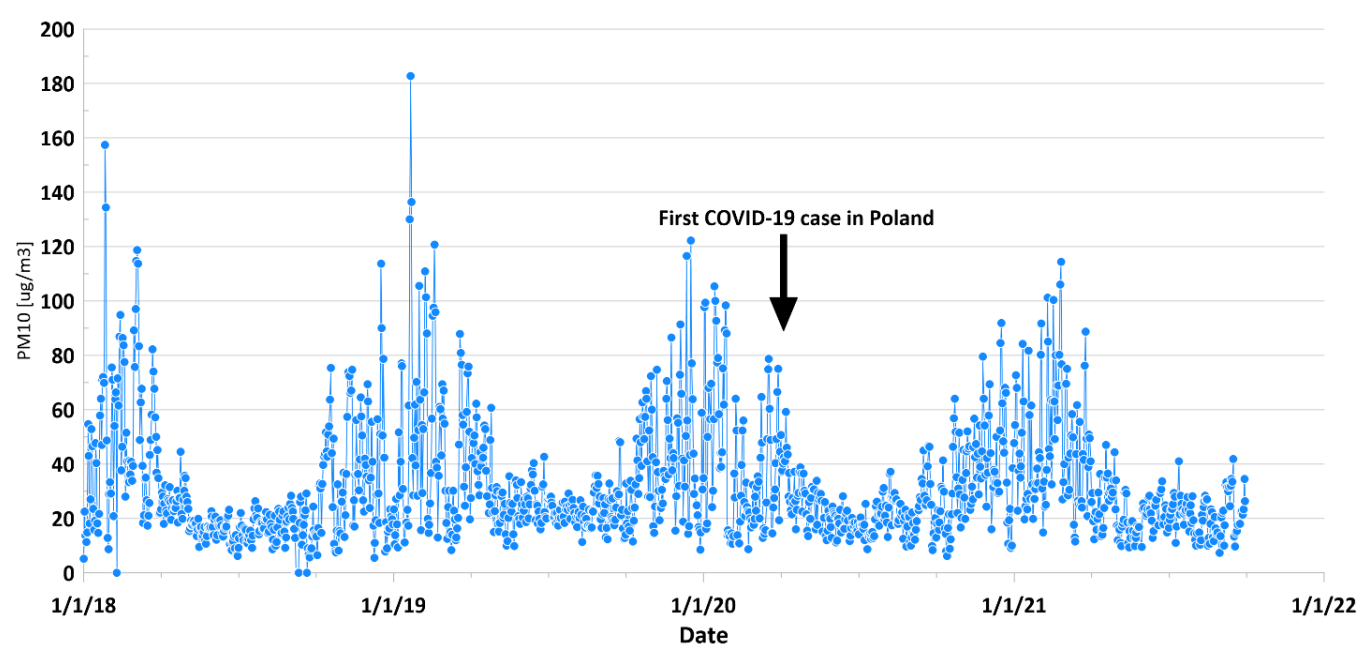

Fig. 3. 24-hour averaged $\mathrm{PM}_{10}$ concentration in Krakow for years 2018-2021. Measurements from reference station located on Bujaka street in Krakow. (Data source: Chief Inspectorate for Environmental Protection, 2021)

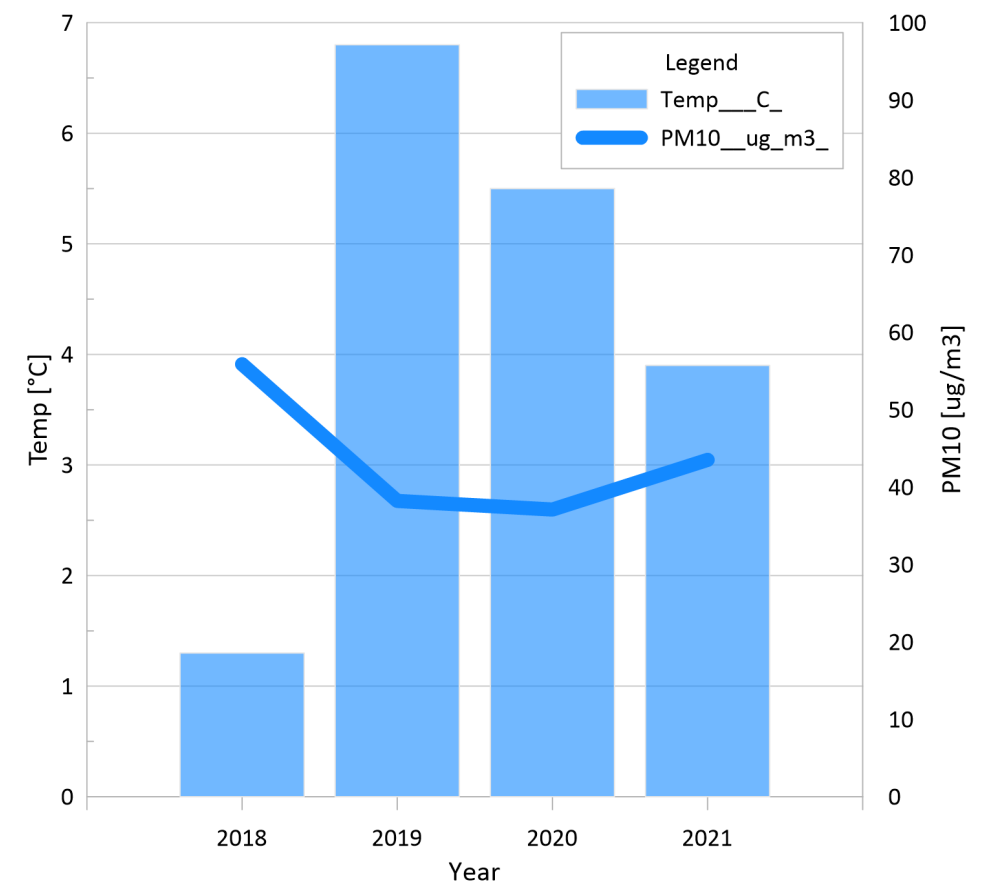

Fig. 4. Average $\mathrm{PM}_{10}$ concentration and temperature in March 2018-2021 (Data source: Chief Inspectorate for Environmental Protection, 2021 and Institute of Meteorology and Water Management - National Research Institute, 2021) 
temperature in March from the year 2018 to 2021, together with the average $\mathrm{PM}_{10}$ concentration. The main factor for $\mathrm{PM}_{10}$ concentration in this month is the temperature. As mentioned before, the main source (over $50 \%$ ) of $\mathrm{PM}_{10}$ pollution in Krakow is solid fuel heating, so naturally, the temperature will have a dominant impact on its concentration. However, in this study, we wanted to examine the effect of $\mathrm{PM}_{10}$ migration from solid fuel heating without additional background noise from car transportation (source of 11-22\% depending on localization in the pre-pandemic year) which were limited during the lockdown. Summing up, the impact of the pandemic on the overall concentration of $\mathrm{PM}_{10}$ in the atmosphere in Krakow is not dominant, however, it is crucial to eliminate the influence of the car transportation background. When analyzing the values in individual years in March, it is not possible to conclude unequivocally about the impact of the lockdown itself, as it is clearly visible that the dominant factor is temperature, which results directly from the specificity of heating houses in the region.

\subsection{Relation between PM Concentration and Other Physical Atmosphere \\ Parameters}

Fig. 5 shows a graph for $\mathrm{PM}_{10}$, temperature, humidity, and pressure measurements for all 90 sensors in the whole investigation period. Fig. 6 demonstrates the relation between $\mathrm{PM}_{10}$ concentration and other physical measurements in the context of the European Air Quality Index. Figs. 6(a) and 6(d) show the relation between temperature and humidity for Krakow city and neighboring municipalities. The relation between pressure and temperature is shown in Fig. 6(b) (Krakow city) and Fig. 6(e) (neighboring municipalities). Finally, the pressure and -humidity relation is demonstrated in Fig. 6(c) (Krakow city) and Fig. 6(f) (neighboring municipalities). The analysis of individual weather factors for $\mathrm{PM}_{10}$ indications is extremely difficult. According to the Czernecki et al. (2017) study, the key factor is wind.

It is clearly visible that a higher concentration of $\mathrm{PM}_{10}$ is strongly related to pressure. When the pressure was below $1005 \mathrm{hPa}$ in the examined spring period, the air quality was good and no matter what the temperature values were. A similar situation is for humidity, only for neighboring municipalities some measurements gave a slightly worse index of air quality for humidity over $60 \%$ for pressure below $1005 \mathrm{hPa}$. The worst air quality index is for pressure range 1005 and $1015 \mathrm{hPa}$, but it changes in the range 1015-1020 hPa where the strong temperature dependence is visible (when dropping below comfort zone (Jendritzky et al., 2001). We can conclude that the highest concentration of $\mathrm{PM}_{10}$ is related to high pressure, low temperature, and high humidity, but with the dominant role of pressure (compare Ning et al. (2018)). These observations are in the line with Wilgosiński and Czerwińska's (2020) study about smog episodes in Poland. They proved that during the cold season high pressure is related to anticyclone circulation of very dry and cold air masses. During the night temperature drops significantly and during the day temperature increase. This situation leads to temperature inversion between cooler ground and warmer atmosphere. When the humidity is relatively low and the temperature is high, the $\mathrm{PM}_{10}$ quality index is good. However, this relation can be distracted by high pressure. This effect can be observed in Fig. 5 - on $29^{\text {th }}$ March, where is a relatively high temperature, low humidity, and high pressure and a noticeable higher concentration of $\mathrm{PM}_{10}$ compared to the previous day where

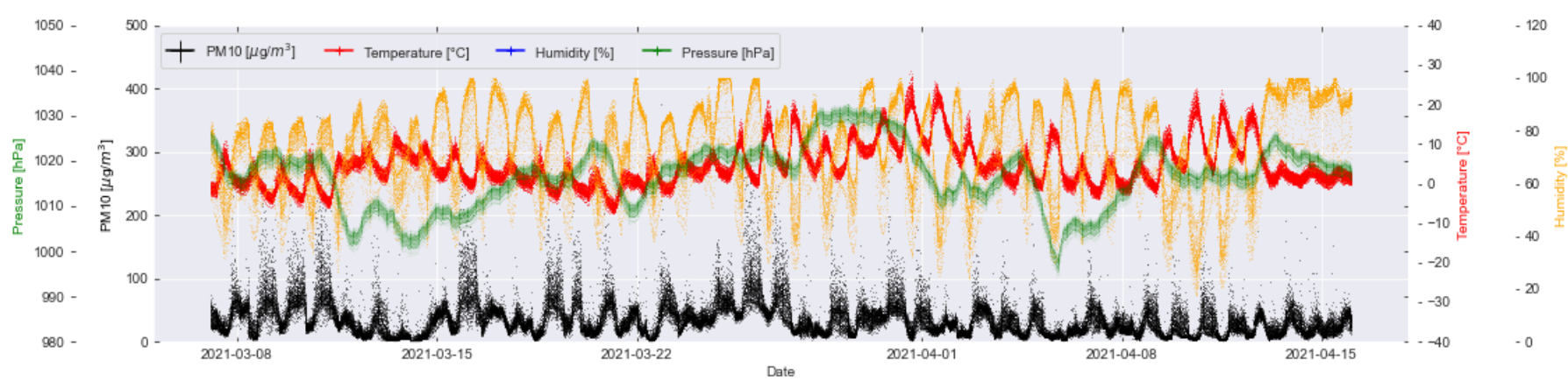

Fig. 5. The pressure (green), humidity (orange), temperature (red), and $\mathrm{PM}_{10}$ (black) in the investigated region from Airly LCS measurements. 
a)

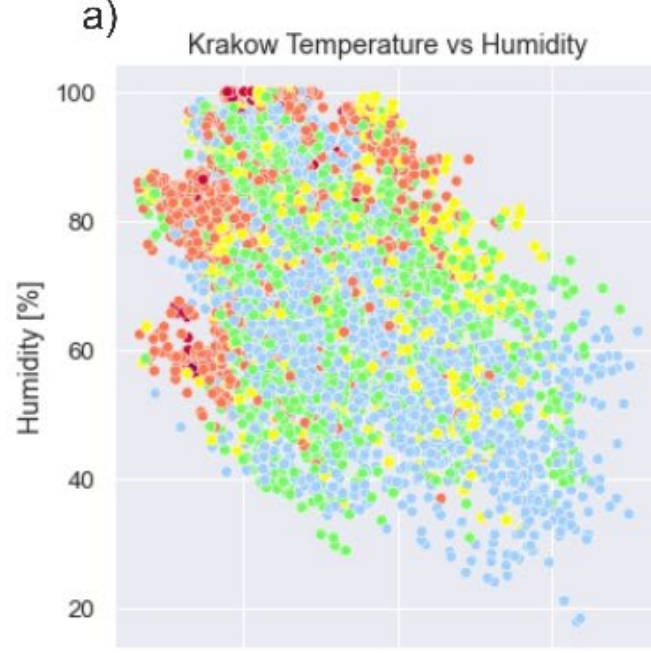

b)

$\begin{array}{lc}0 & 10 \\ & \text { Temperature }\left[{ }^{\circ} \mathrm{C}\right]\end{array}$
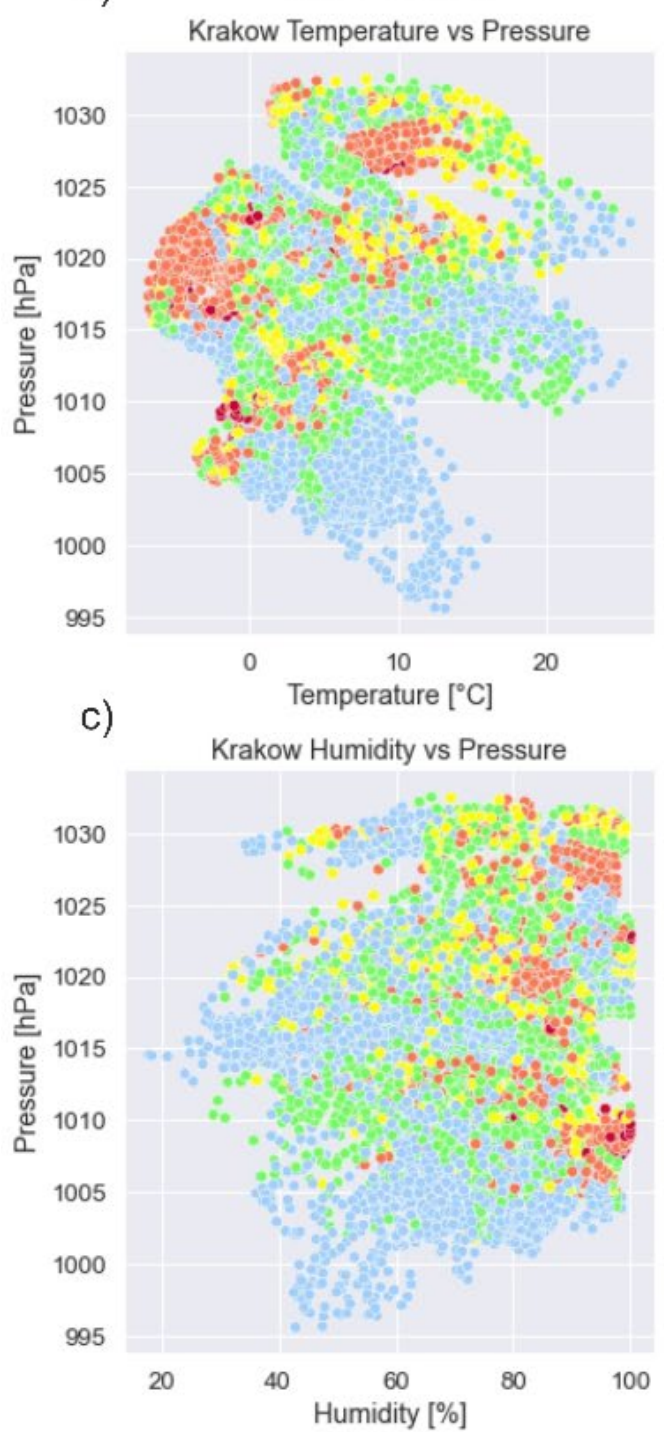

d)

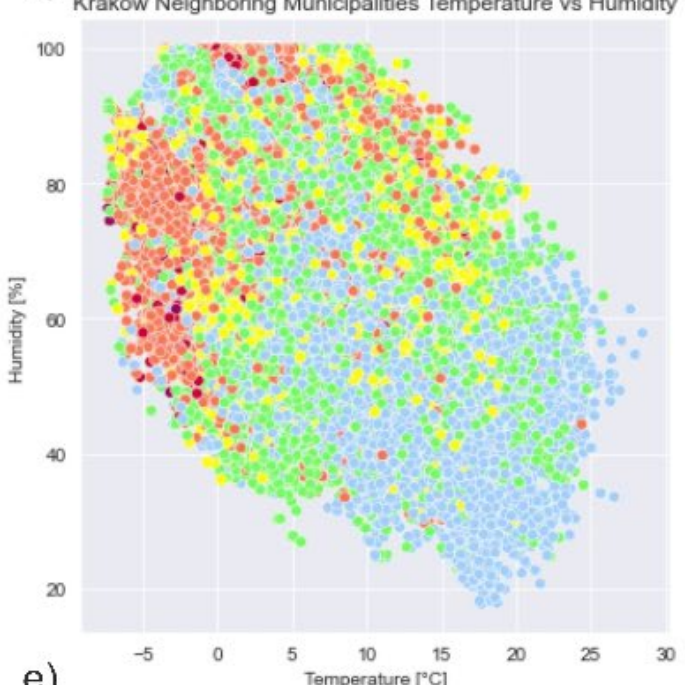

Krakow Neighboring Municipalities Temperature vs Pressure

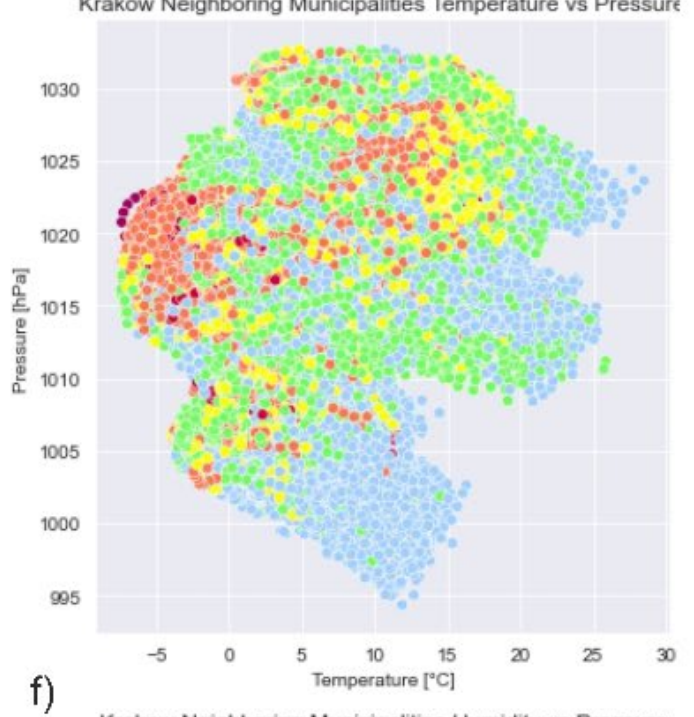

f)

Krakow Neighboring Municipalities Humidity vs Pressure

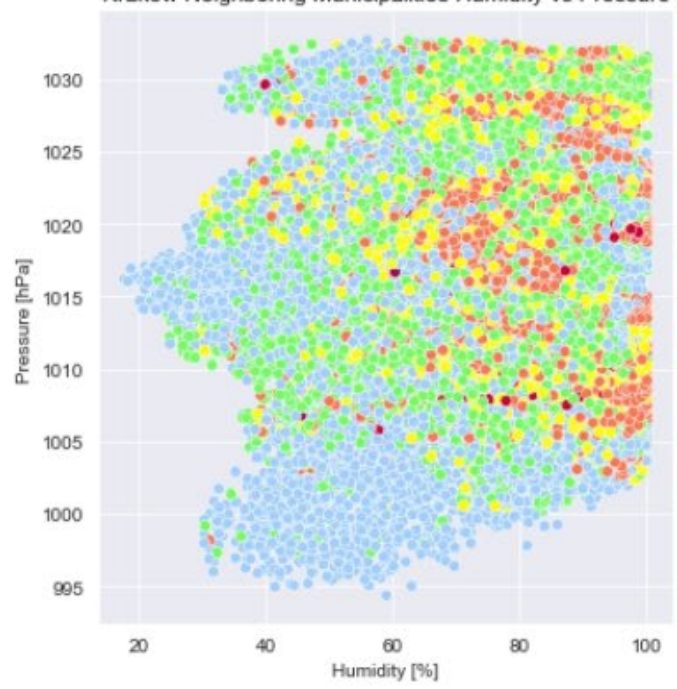

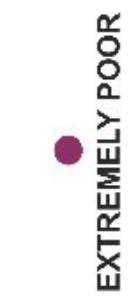

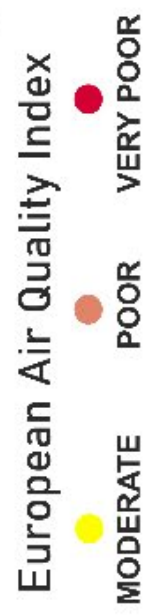

$\frac{\underline{\alpha}}{4}$

응

Fig. 6. Cross-plots for physical atmosphere parameters measured in sensors during spring divided into groups according to European Air Quality Factor - (a) relation between humidity and (d) temperature in Krakow and neighboring municipalities; (b) the relation between pressure and temperature in Krakow and (e) neighboring municipalities; (c) the relation between pressure and humidity in Krakow and ( $f$ ) neighboring municipalities. 
pressure was much lower. According to Zhang et al. (2017) study, the effect of the humidity on PM concentration while atmospheric conditions are stable is low, however, relative humidity fluctuations can have a strong impact on pollutions concentration.

To aggregate information from the regions of interest, namely west, north and Krakow groups we calculated daily averages and standard deviations of all available $\mathrm{PM}_{10}$ readings from LCS stations in a particular group (see Fig. 7) and averages of meteorological factors (see Fig. 8). Results obtained for temperature, humidity, and pressure are nearly identical in all groups whereas $\mathrm{PM}_{10}$ averages differ substantially. As expected readings from Krakow city are more similar to readings from the west group. This effect is cost by the dominant west wind direction. In general, values obtained for Krakow city are lower than those obtained for the west group, but in the days when the west wind is relatively stable and not too strong (e.g., March $16^{\text {th }}$ ) difference between these values disappears. Daily average uncertainties of $\mathrm{PM}_{10}$ concentration measurements for Krakow and the north group are lower than those obtained for the west group. It may suggest more local character of emission in this group.

\subsection{Analysis of Air Pollution Inflow Concerning Main Wind Direction}

It has been shown that the migration of PM from neighboring municipalities to Krakow city, on days with no wind takes place by gravity fall or by diffusion as the city is located in the valley (Danek and Zaręba, 2021). Our goal was to check how the migration process of air pollutions depends on an additional external factor like the wind. During the studied period, the dominant wind direction was west (see Fig. 9). In the examined period the highest wind speed is related to wind direction SW. The south direction can be associated with a strong Foehn wind type which, under favorable conditions, may even have an impact on the regions of central Poland. This is a kind of warm and dry wind associated with the downwind slope of the mountain range (Marcinek et al., 2016). There were a few days with dominant north wind direction. For example, the good conditions for observation the inflow of $\mathrm{PM}_{10}$ to Krakow was the night between $15^{\text {th }}$ and $16^{\text {th }}$ March. In Fig. 5 it is clearly visible that those days are a part of days in the period when the increasing trend of pressure and decreasing trend of temperature with relatively high, stable
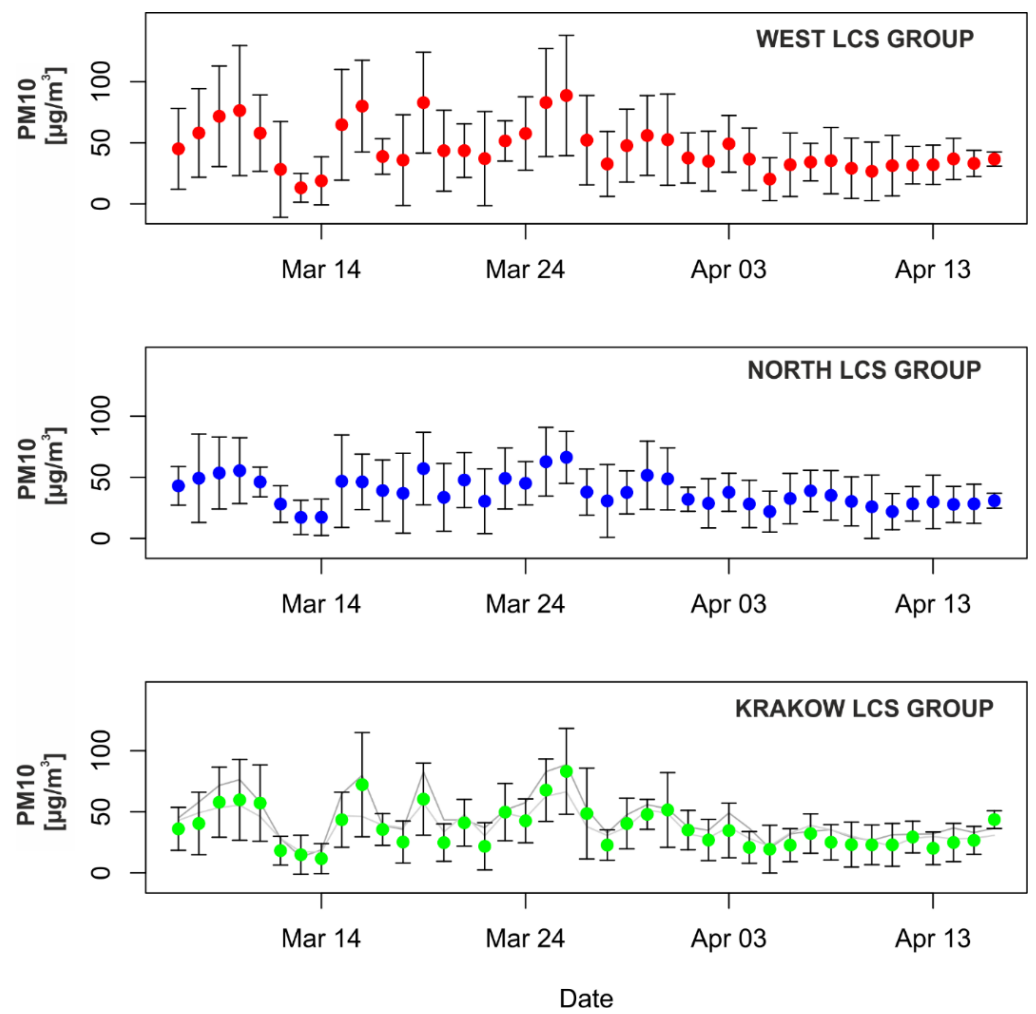

Fig. 7. Daily averaged $\mathrm{PM}_{10}$ Airly LCS measurements in the three groups: west (red), north (blue), and Krakow city (green). 

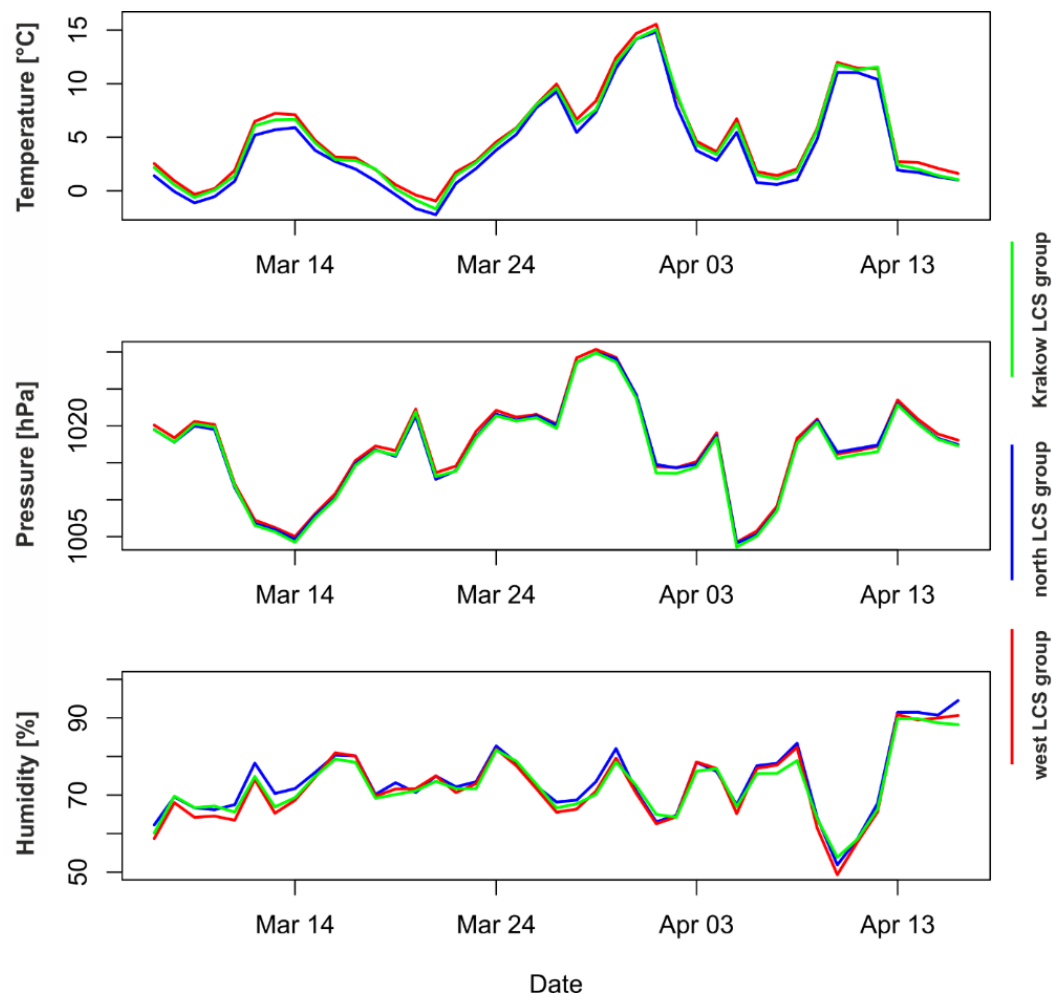

Fig. 8. Daily averaged meteorological factors for the three groups: west (red), north (blue), and Krakow city (green).

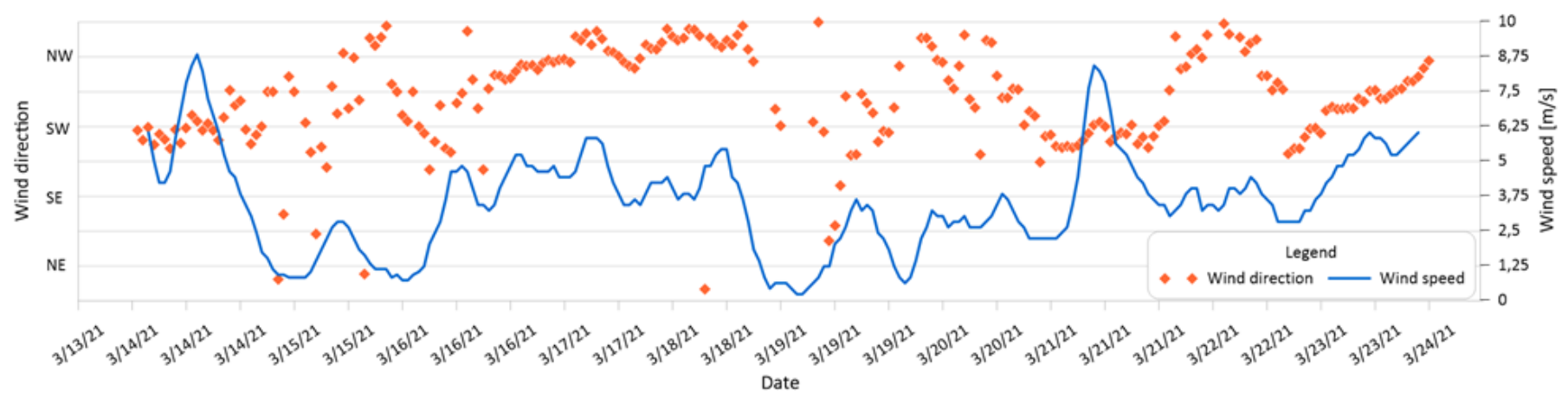

Fig. 9. Wind direction (orange) and wind speed (blue) for Krakow-Balice meteorological station (data source: Institute of Meteorology and Water Management - National Research Institute, 2021).

humidity are present. Furthermore, the temperature at the night is lower than in the next two days, even if the general 24-hour temperature is decreasing. The temperature on this night drop below comfort zone temperature and it is the main factor of increased heating of the households and therefore the main factor for generating air pollution as well.

\subsubsection{The inflow of pollution when the dominant wind direction is west}

Fig. 10 presents maps of $\mathrm{PM}_{10}$ inflow to Krakow city on the night between $15^{\text {th }}$ and $16^{\text {th }}$ March in hours: 19:00 $15^{\text {th }}$ March; 01:00 $16^{\text {th }}$ March; 02:00 $16^{\text {th }}$ March; 06:00 $16^{\text {th }}$ March. This is the time when car traffic in Krakow is close to zero. Additionally, the lockdown is a factor reducing population mobility resulting in reduced possible migration of pollutants generated by car traffic at other times of the day. As in Krakow and neighboring municipalities, two main PM sources are related to heating and transportation, we can conclude that the observed pollution is generated by solid fuels heating in neighboring municipalities. It is clearly visible that in the evening there is generally 

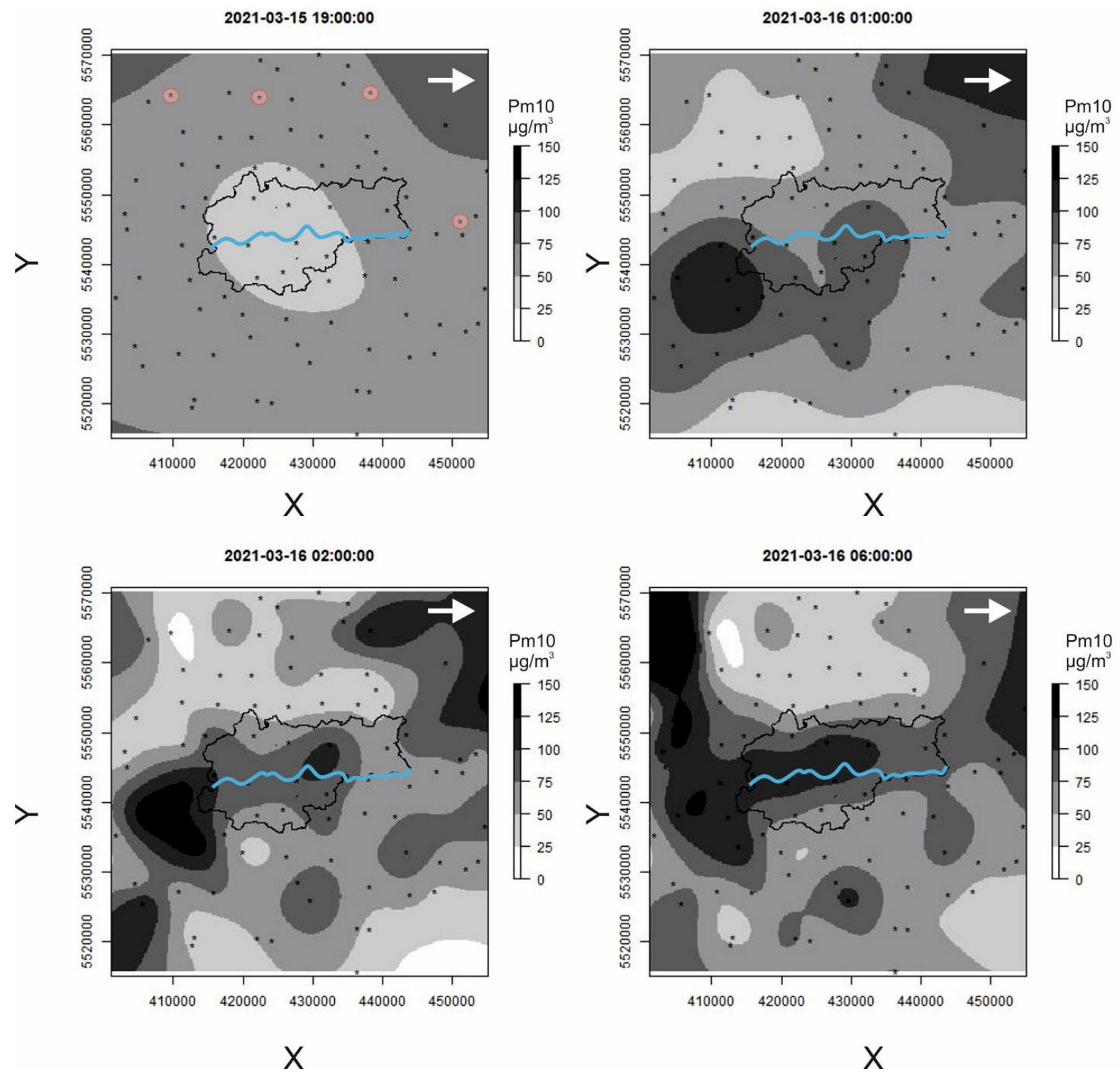

Fig. 10. Maps of $\mathrm{PM}_{10}$ inflow with west dominant wind direction in the night between $15^{\text {th }}$ and $16^{\text {th }}$ March. White arrows indicate wind direction. Asterisks represent sensors' localizations, the blue line represents the Vistula River, red circles represent sensors with high residual value.

an increased level of $\mathrm{PM}_{10}$ concentration in neighboring municipalities while the air in Krakow city beside Nowa Huta region is pretty good. After midnight, when the temperature dropped significantly the higher concentrations of $\mathrm{PM}_{10}$ are visible in western regions. Wind speed is around $2 \mathrm{~km} \mathrm{~h}^{-1}$. Fig. 11 shows the wind-rose diagram for the Krakow-Balice airport station (located on the northwest side of the investigated area) (calculated using https://mesonet.agron.iastate.edu/). In the next hour, the pollutants are transported to the city center through the Vistula River valley, to finally fill the city in a latitudinal arrangement around 6:00 $16^{\text {th }}$ March. The distribution of isolines is latitudinal with the highest concentration of $\mathrm{PM}_{10}$ along with the river line and the lowest to the south and north of this line. The local depression along the river valley, the higher humidity in this area, and the tendency to form mists create a favorable environment for trapping transported pollutants in this area. Fig. 12 shows a backward trajectory for 10 hours on that day for 3 different locations in Krakow agglomeration. The trajectories were calculated using READY (Real-time Environmental Applications and Display sYstem) provided by National Oceanic and Atmospheric Administration (Rolph et al., 2017). It is clearly visible that possible pollutant comes from the north and west surrounding of Krakow. 


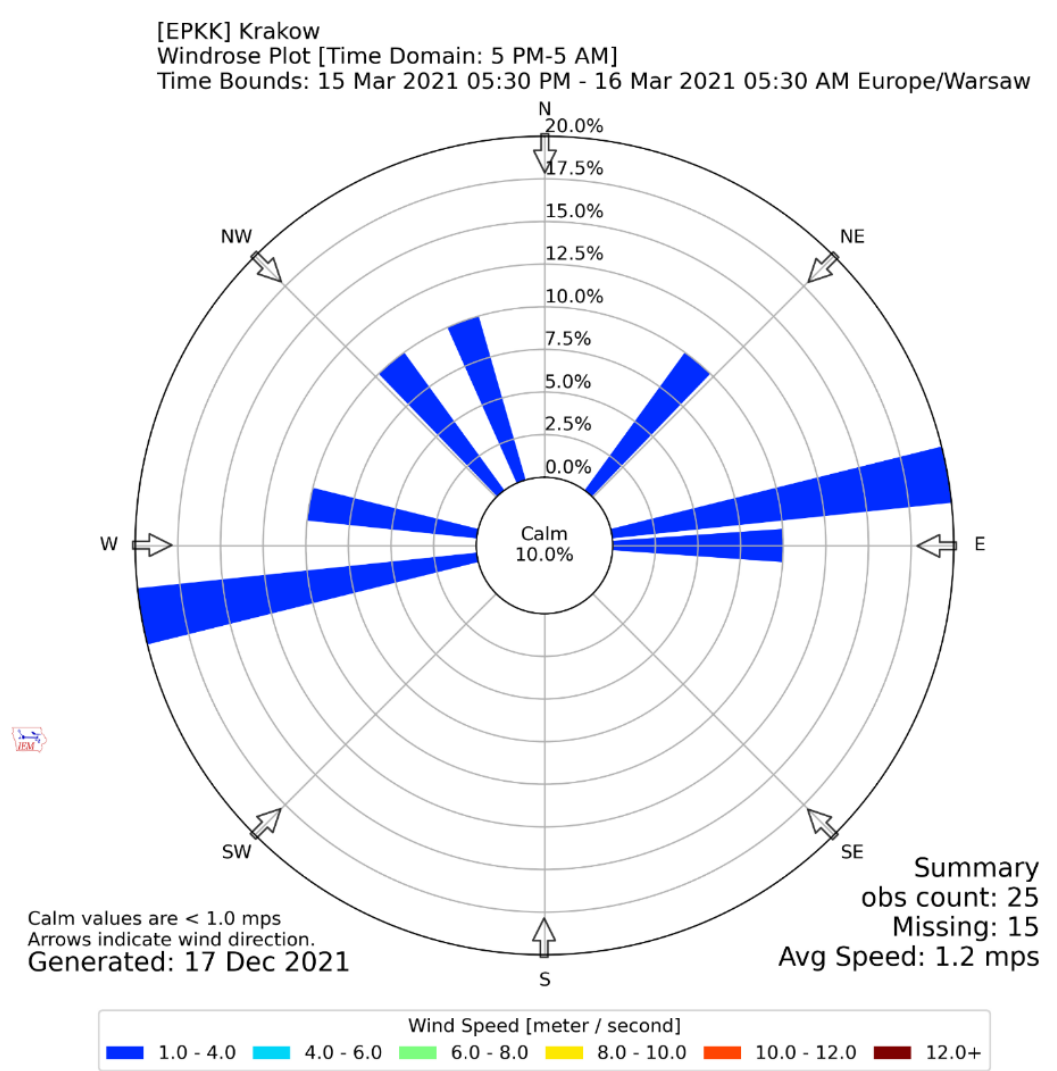

Fig. 11. The wind rose for Krakow-Balice airport meteorological station on March $15^{\text {th }}$ and March $16^{\text {th }}$ for time bounds 17:30-05:30. (lowa Environmental Mesonet, 2021)

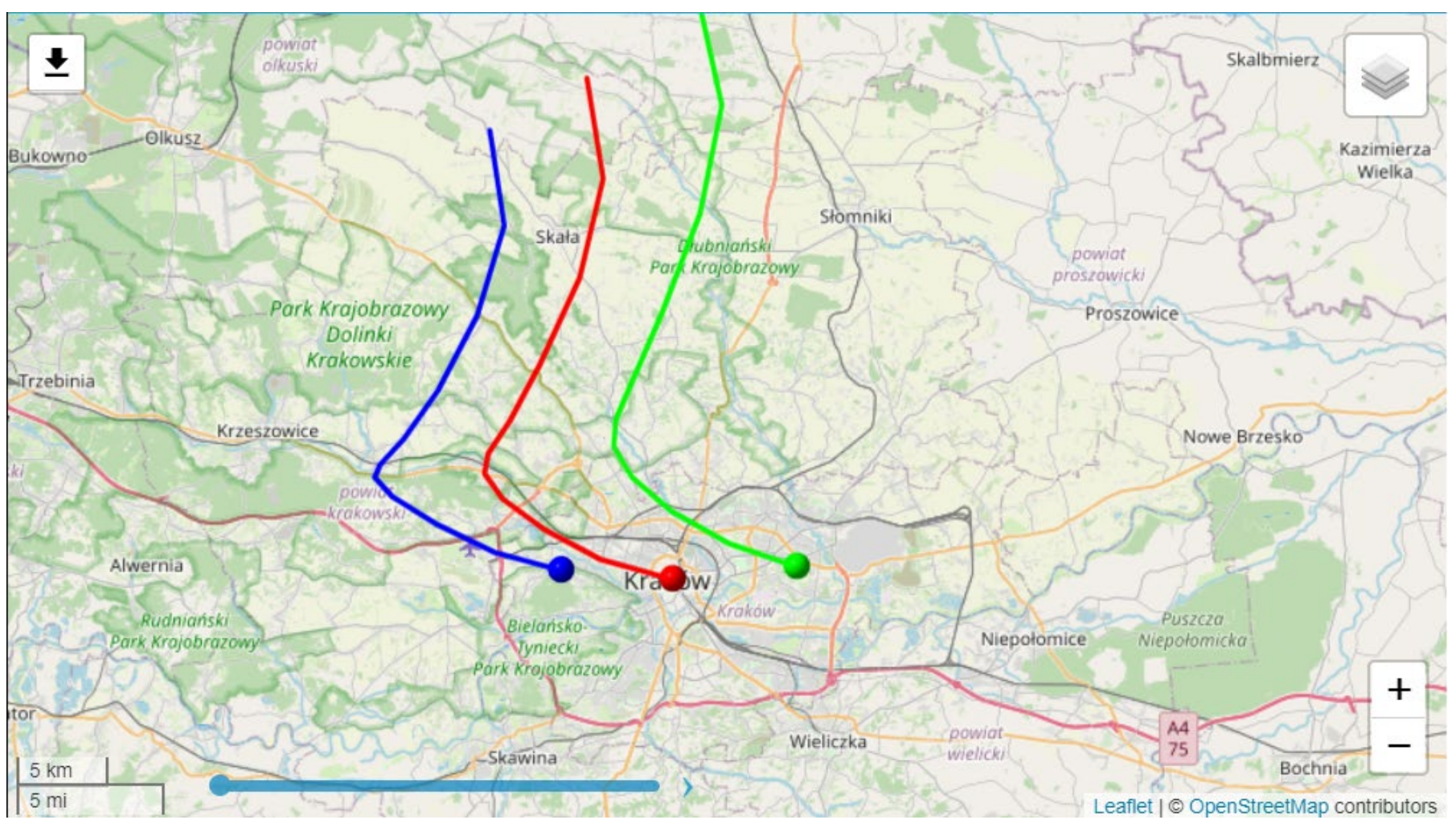

Fig. 12. Map of backward trajectory with ending time 19:00 on March $15^{\text {th }}$ according to NOAA HYSPLIT model. (Map source OpenStreetMap and Leaflet, 2021) 


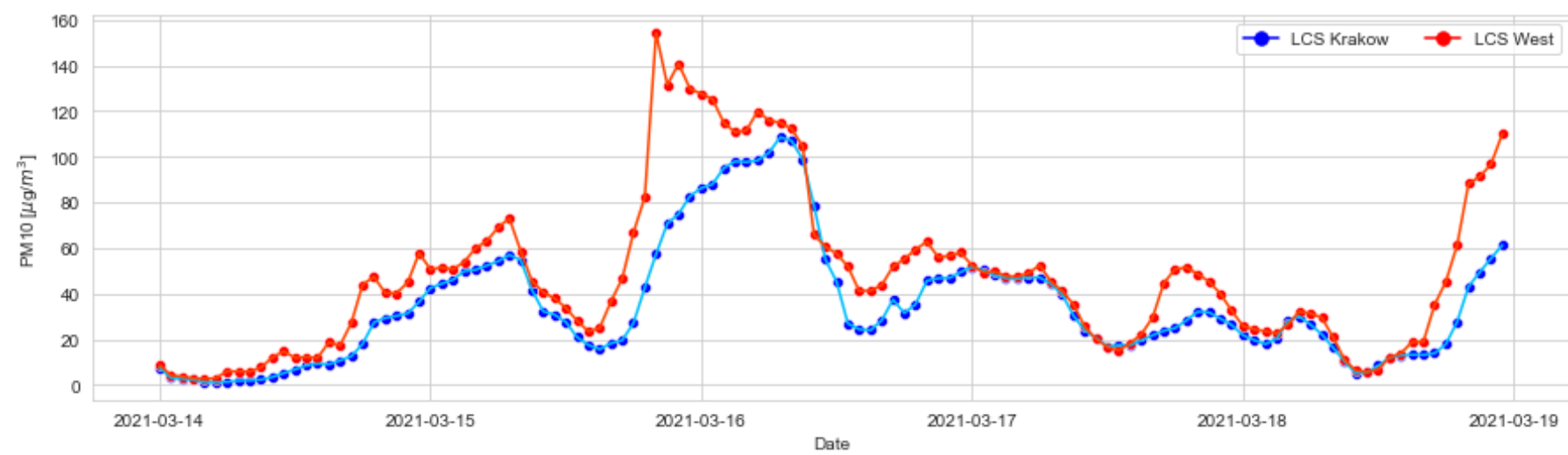

Fig. 13. Averaged $\mathrm{PM}_{10}$ concentration in Krakow (blue) and a west group of sensors outside the city (red) from $14^{\text {th }}$ to $19^{\text {th }}$ March 2021.

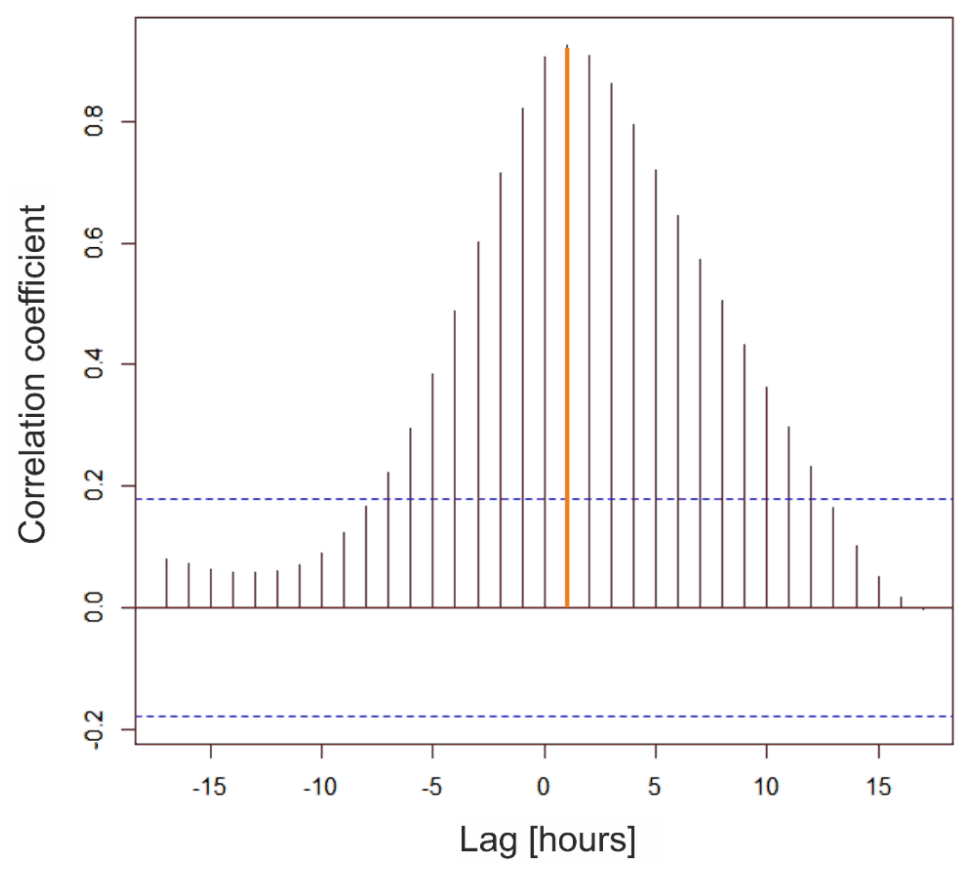

Fig. 14. The autocorrelation function of averaged $\mathrm{PM}_{10}$ concentration series for west sensor group and Krakow sensors from $14^{\text {th }}$ to $19^{\text {th }}$ March 2021. The Blue dashed line represents statistical significance, the orange line represents maximum lag.

Fig. 13 shows two-time series - the blue line represents averaged $\mathrm{PM}_{10}$ values in Krakow city, and the red line shows averaged $\mathrm{PM}_{10}$ values for the west sensors group outside the city. The effect of locally highest emission on March $16^{\text {th }}$ is clearly visible for both areas. Average values of $\mathrm{PM}_{10}$ concentration in the previous two days, and the following two days are noticeably lower. As mentioned before, mostly due to the minimal temperature value in the night between $15^{\text {th }}$ and $16^{\text {th }}$ March, which dropped around $0^{\circ}$ Celsius. The lag between the maximum pollution point for west group sensors and the sensors in Krakow is visible. Fig. 14 shows the calculated lag value for those two time series for the same period as on the graph in Fig. 13. In general, the distribution for sensors in Krakow city is lagged about 1 hour compared to sensors in the west group.

\subsubsection{The inflow of pollution when the dominant wind direction is north}

Fig. 15 presents maps of $\mathrm{PM}_{10}$ inflow to Krakow city on the night and early morning on $18^{\text {th }}$ March in hours: 02:00, 03:00, 04:00, 05:00. Again we choose hours when the car traffic is very low and when the effect of households heating can be observed as the temperature is below the 

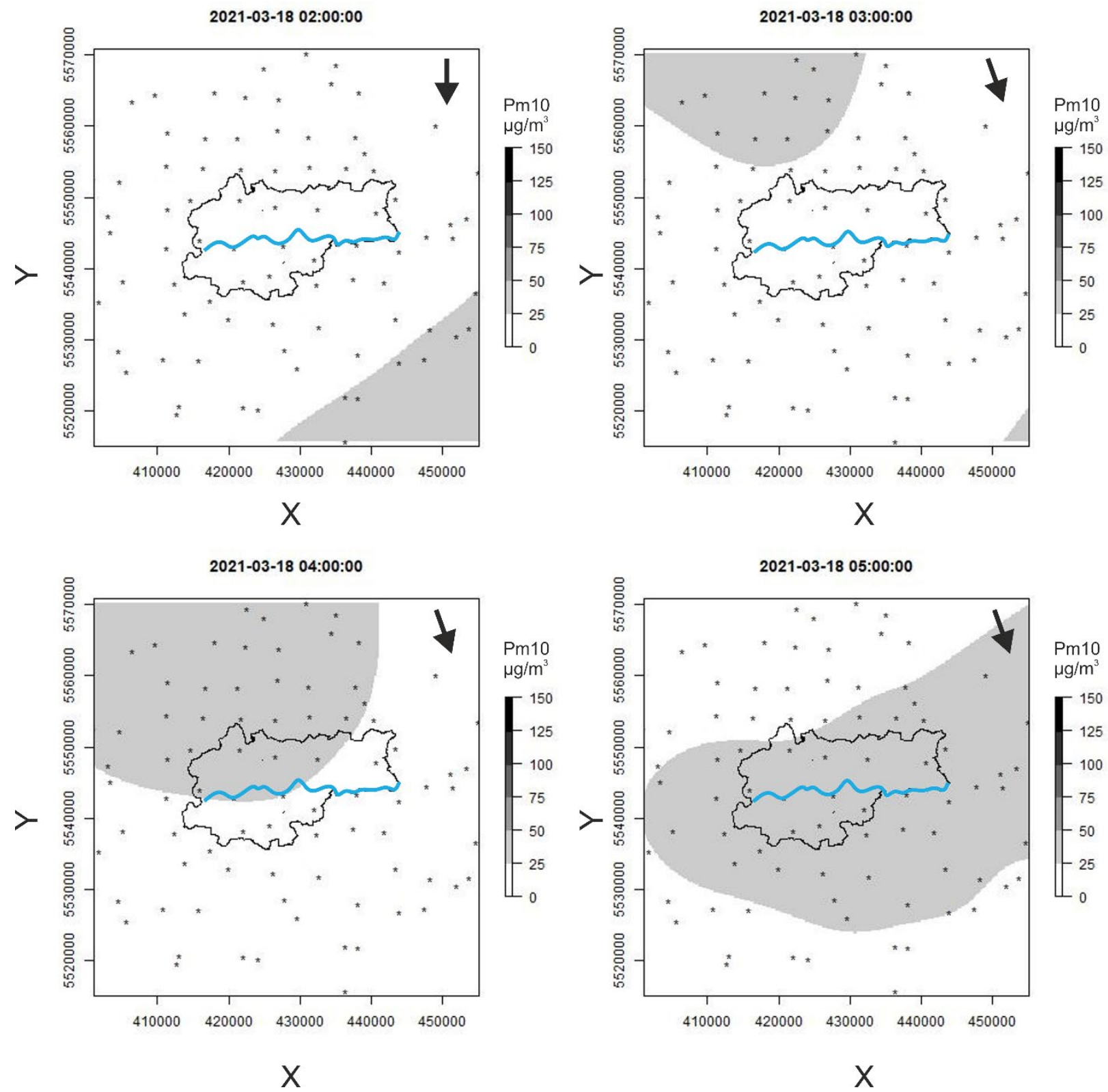

Fig. 15. Maps of $\mathrm{PM}_{10}$ inflow with north dominant wind direction in the night and early morning on $18^{\text {th }}$ March. Black arrows indicate wind direction. Asterisks represent sensors' localizations, the blue line represents the Vistula River.

comfort zone (Jendritzky et al., 2001). We can say with certainty that the impact of PM sources other than those coming from heating is negligible at these times, especially during the period of partial lockdown with a relatively cold night. On that day around 02:00, Krakow and neighboring municipalities' air was very good. The situation started to change about 3:00 when the higher concentration of $\mathrm{PM}_{10}$ began to form in the northern area of investigated region. The dominant wind direction on that day was north and north-north-west. Fig. 16 shows the wind-rose diagram on $18^{\text {th }}$ March - again for the Krakow-Balice airport station. In the next hour the pollutions were transferred into the north region of Krakow city - to the Bronowice, Prądnik Biały, Prądnik Czerwony and Krowodrza. In the next hour, the pollutions were in the whole city and also in Wieliczka and other cities in the south of Krakow. For the rest of this day, there was no wind and the temperature was around 6-8 Celsius degrees. Later in the evening on this day, the effect of diffusion and gravity fall of pollutants into the city was shown by Danek and Zaręba (2021). Fig. 17 shows a backward trajectory for 10 hours on that day for 3 different locations in Krakow. The trajectories were again calculated using READY. It is clearly visible that pollutants entered Krakow from the north. 


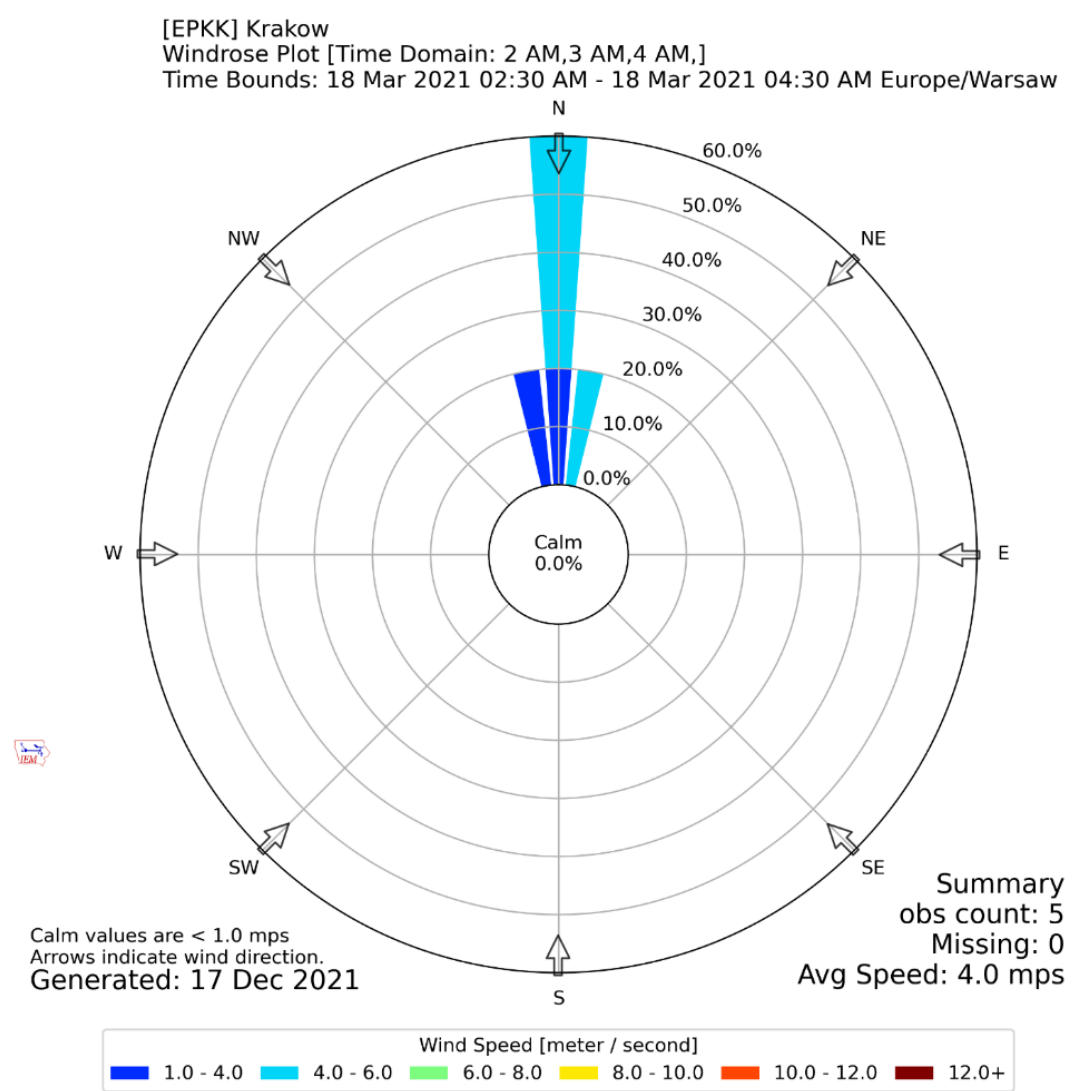

Fig. 16. The wind rose for Krakow-Balice airport meteorological station on March $18^{\text {th }}$ for time bounds 02:30-04:30 (lowa Environmental Mesonet, 2021).

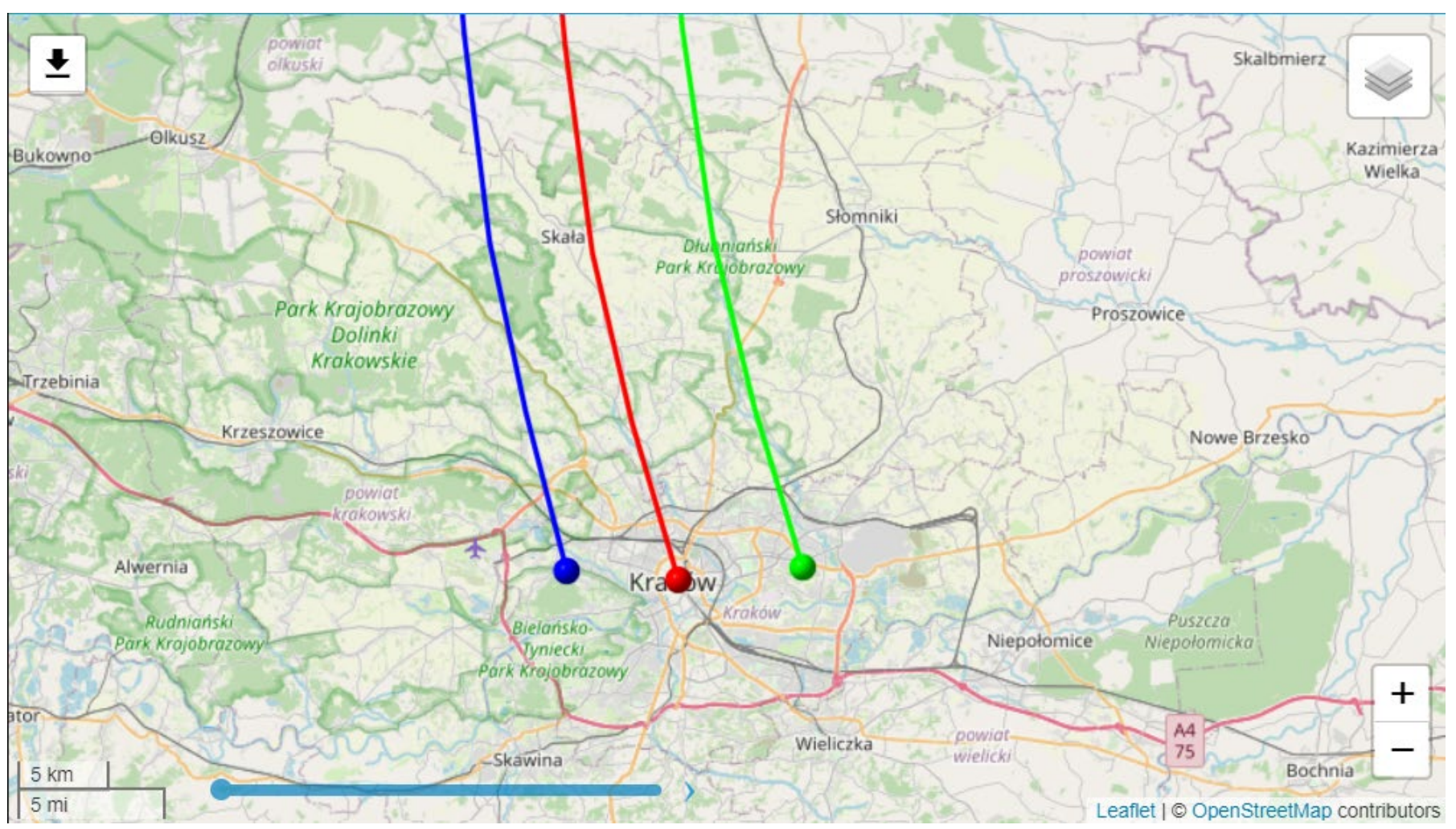

Fig. 17. Map of backward trajectory with ending time $02: 00$ on March $18^{\text {th }}$ according to NOAA HYSPLIT model. (Map source OpenStreetMap and Leaflet, 2021) 
Fig. 18 shows two-time series - similar to those in Fig. 13. Blueline again represents averaged $\mathrm{PM}_{10}$ values in Krakow city but the red line shows averaged $\mathrm{PM}_{10}$ values for the north sensors group outside the city. The situation is slightly different than presented in the example before. Here there are the following days on steadily decreasing temperature trend with a clear uptrend for pressure. We can observe continuous lag between sensors outside and inside Krakow. Of course, the lag for the maximum pick on $18^{\text {th }}$ March 01:00 for the north sensors group and sensors in Krakow is mostly dominated by the wind. The pollutants are transported to Krakow, but on the other hand in presence of north wind, they are quickly blown out from the city to the south. In the next days presented on this graph, the wind speed is very low, close to zero, so the higher concentration of $\mathrm{PM}_{10}$ transported into the city remains there longer as the city is located in the valley. Fig. 19 shows also the 2 hours lag between distribution for the north group of sensors and sensors in Krakow. It seems that the terrain causes that pollution flowing in from the north takes longer to enter the city than when it enters the Vistula valley from the west. It is a valuable observation in the case of the future forecasting of the pollution level in Krakow city.

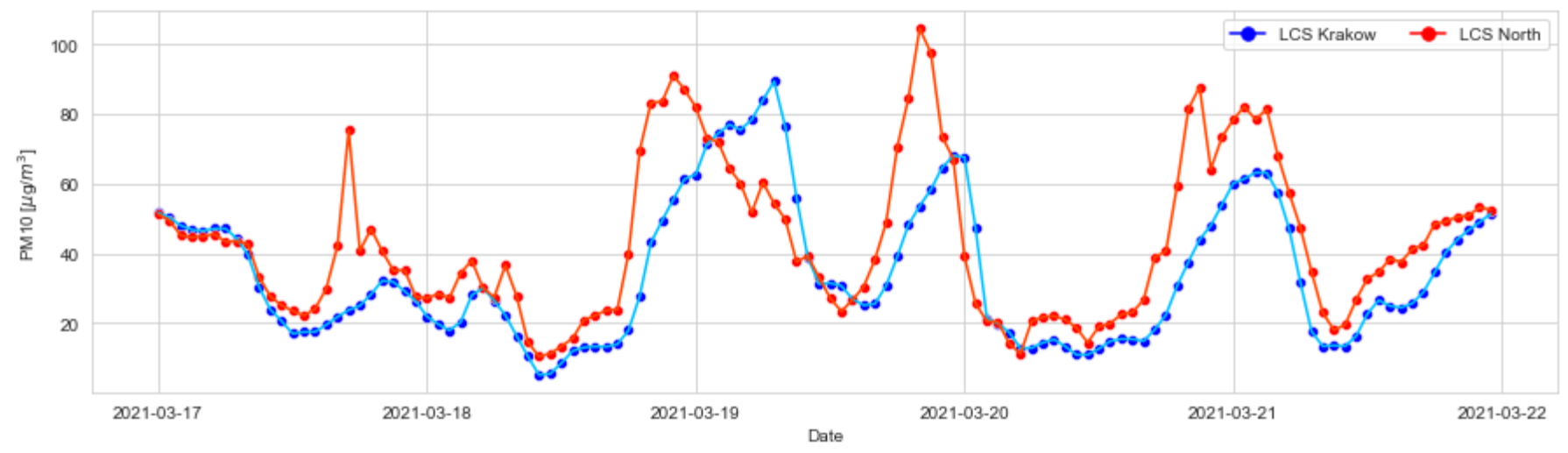

Fig. 18. Averaged $\mathrm{PM}_{10}$ concentration in Krakow (blue) and a north group of sensors outside the city (red) from $17^{\text {th }}$ to $22^{\text {nd }}$ March 2021.

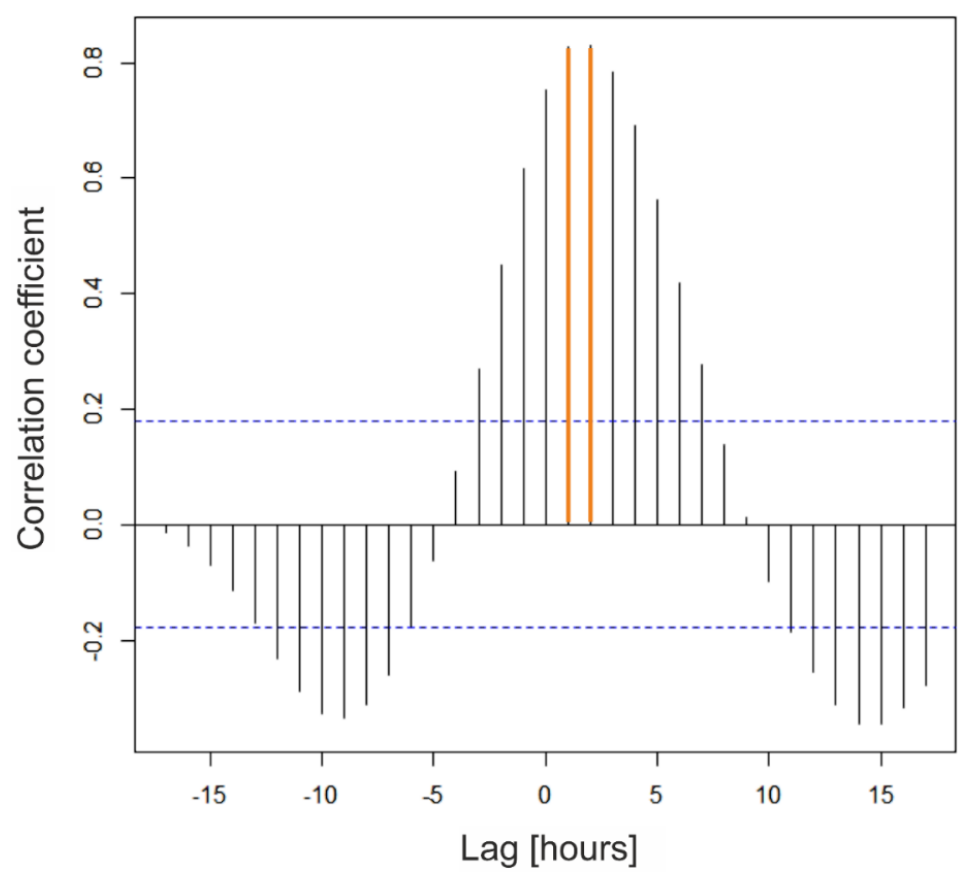

Fig. 19. The autocorrelation function of averaged $\mathrm{PM}_{10}$ concentration series for north sensor group and Krakow sensors from $17^{\text {th }}$ to $22^{\text {nd }}$ March 2021. The Blue dashed line represents statistical significance, the orange line represents maximum lag. 


\section{CONCLUSIONS}

The conducted research clearly shows that pollutants generated in neighboring towns are transported with the wind to Krakow city. With a specific system of pressure, temperature and humidity, they can remain in the city to which they were transported for a long time. This situation can be even worst during the cold season when the Polish-type smog occurs (Wielgosiński and Czerwińska, 2020) Due to the partial lockdown introduced by the Polish government the PM concentration noise from transportation was limited and observation of the almost clear effect from solid fuels heating was possible. In addition, the analyses were carried out in temporal windows, in which car traffic was minimal. The temperature was also low enough and inhabitants of neighboring municipalities had to heat their houses. An important observation is that the west wind is conducive to the rapid transport of pollution to the city. Even if the wind speed is relatively low. Backward propagation study showed that pollutants emitted in the north can easily enter the city through the west air gate. The maximum $\mathrm{PM}_{10}$ concentration with the domination of these winds coincides with the Vistula River valley. The Vistula valley runs through important and historical parts of the city with increased tourist traffic, which may make Krakow's visitors feel that the city is a smog generator itself, while Krakow has one of the most pro-cleanair legislation in Poland in force. The lag between increased pollution in neighboring cities on the west and pollution increase in Krakow is about 1 hour. In the case of days when the north wind is dominant, the lag is about 2 hours. It is related probably to a natural barrier of hills on the north side. What is more, in presence of north wind, the pollutions are transported out much faster than it was when west winds occurred.

Banning the use of solid fuels for heating in selective cities does not relieve these cities from the air pollution problem related to solid fuels. It is important to extend the ban on solid fuel use for heating in Krakow to other localities in the Krakow agglomeration. Firstly, because of the health of the inhabitants of these particular towns, but also for the health of the inhabitants of Krakow. The research cited in the introduction clearly shows the facts of a health problems occurrence associated with exposure to air pollution. Secondly, because of the tourist traffic. After the transformation period, Krakow has become one of the most visited cities in Europe (KowalczykAnioł et al., 2021), therefore taking care of the positive perception of the city, including clean air, is in the interest of the inhabitants of the region working in the tourism industry.

\section{ACKNOWLEDGMENTS}

This research was supported by AGH-University of Science and Technology, Faculty of Geology, Geophysics and Environmental Protection-as a part of the statutory project.

Publicly available datasets from Airly sensors were analyzed in this study. This data can be found here: (https://map.airly.org/, accessed on 29 September 2021). Airly API documentation is available here: (https://developer.airly.org/en/docs, accessed on 29 September 2021).

\section{REFERENCES}

Agafonkin, V. (2021). Leaflet 1.7.1 https://leafletjs.com/ (accessed 17 December 2021).

Airly (2021a). Airly Air Quality Sensors PRODUCT CARD. https://www.danintra.dk/pdf/Danintra Airly.pdf (accessed 18 December 2021).

Airly (2021b). Artificial Intelligence in the Airly's air quality prediction system. https://airly.org/en/ artificial-intelligence-in-the-airlys-air-quality-prediction-system/ (accessed on 18 December 2021).

Bokwa, A. (2007). Air pollution. in: Matuszko, D. (Ed.), The climate of Cracow in the $20^{\text {th }}$ century, Institute of Geography and Spatial Management, Jagiellonian University, Cracow, pp. 187-199 (in Polish).

Bokwa, A. (2008). Environmental impacts of long-term air pollution changes in Kraków, Poland. Polish J. Environ. Stud. 17, 673-686.

Bokwa, A. (2019). Rozwój badań nad klimatem lokalnym Krakowa. Acta Geogr. Lodz. 108, 7-20. https://doi.org/10.26485/AGL/2019/108/1 (in Polish) 
Briggs, J.D., Collins, S., Elliott, P., Fischer, P., Kingham, S., Lebret, E., Pryl, K., Van Reeuwijk, H., Smallbone, K., Van Der Veen, A. (2010). Mapping urban air pollution using GIS: A regressionbased approach. Int. J. Geog. Inf. Sci. 11, 699-718. https://doi.org/10.1080/136588197242158

Chief Inspectorate for Environmental Protection (2021). PMs Measuring in the Air. http://www.gios.gov.pl/pl/aktualnosci/391-pomiary-pylu-zawieszonego-w-powietrzu (accessed 29 September 2021).

Czernecki, B., Półrolniczak, M., Kolendowicz, L., Marosz, M., Kendzierski, S., Pilguj, N. (2017). Influence of the atmospheric conditions on $\mathrm{PM}_{10}$ concentrations in Poznań, Poland. J. Atmos. Chem. 74, 115-139. https://doi.org/10.1007/s10874-016-9345-5

Dai, L., Zanobetti, A., Koutrakis, P., Schwartz, J.D. (2014). Associations of fine particulate matter species with mortality in the United States: A multicity time-series analysis. Environ. Health Perspect. 122, 837-842. https://doi.org/10.1289/ehp.1307568

Danek, T., Zaręba, M. (2021). The use of public data from low-cost sensors for the geospatial analysis of air pollution from solid fuel heating during the COVID-19 pandemic spring period in Krakow, Poland. Sensors 21, 5208. https://doi.org/10.3390/s21155208

Dębkowska, K., Kłosiewicz-Górecka, U., Szymańska, A., Ważniewski, P., Zybertowicz, K. (2019). Akademickość polskich miast. Polski Instytut Ekonomiczny, Warszawa. (in Polish)

Drużkowski, M. (1992). Wpływ ukształtowania terenu i miejskiej wyspy ciepła na stosunki termiczne Krakowa i okolic. Folia Geog., Ser. Geogr.-Phys. 23, 55-63. (in Polish)

European Commission (2021). Eures - Labour market information. https://ec.europa.eu/eures/ main.jsp?catld=2795\&acro=Imi\&mode=\&recordLang=pl\&lang=en\&parentld=\&countryld=PL\& regionld=PL2 (accessed 08 October 2021).

European Parliament (2008). Directive 2008/50/EC of the European Parliament and of the Council of 21 May 2008 on Ambient Air Quality and Cleaner Air for Europe. http://eurlex.europa.eu/legal-content/en/ALL/?uri=CELEX:32008L0050 (accessed 29 September 2021).

Foldvary, G. (1998). Geology of the Carpathian Region. World Scientific Publishing, Sydney, Australia.

General Directorate for National Roads and Motorways (2021). Ruch na drogach krajowych w czasie epidemii. Podsumowujemy cały marzec 2021 r. https://www.archiwum.gddkia. gov.pl/pl/a/41090/Ruch-na-drogach-krajowych-w-czasie-epidemii-Podsumowujemy-calymarzec-2021-r (accessed 8 October 2021).

Gerboles, M., Spinelle, L., Borowiak, A. (2017). Measuring Air Pollution with Low-Cost Sensors. European Commission. JRC107461. https://ec.europa.eu/environment/air/pdf/Brochure\%20l ower-cost\%20sensors.pdf (accessed 29 September 2021).

Gradziński, R. (1972). Przewodnik geologiczny po okolicach Krakowa. Wydawnictwa Geologiczne, Warszawa. (in Polish)

Hrehorowicz-Gaber, H. (2015). Role of green areas for space integration of Kraków's Metropolitan Area. Bull. Geogr. Socio-Econom. Series 28, 69-76. https://doi.org/10.1515/bog-2015-0016

Hysenaj, M. (2016). Geospatial analysis of environment pollution. J. Ecol. Eng. 17, 10-17. https://doi.org/10.12911/22998993/61184

Institute of Environmental Protection - National Research Institute and the National Centre for Emission Management (2019). Krajowy bilans emisji $\mathrm{SO}_{2}, \mathrm{NO}_{x}, \mathrm{CO}, \mathrm{NH}_{3}, \mathrm{NMLZO}$, pyłów, metali ciężkich i TZO za lata 2015 - 2017. https://www.kobize.pl/uploads/materialy/materialy_do_ pobrania/krajowa_inwentaryzacja_emisji/Bilans_emisji_za_2017.pdf (accessed 18 December 2021). (in Polish)

Institute Of Environmental Protection - National Research Institute and The National Centre for Emission Management (2021). Measurement data. http://powietrze.gios.gov.pl/ (accessed 18 December 2021).

Institute of Meteorology and Water Management - National Research Institute (2021). Dane publiczne IMGW-PIB. https://danepubliczne.imgw.pl/ (accessed 18 December 2021).

lowa Environmental Mesonet of lowa State University (2021). Wind Roses. State University or the State of lowa. https://mesonet.agron.iastate.edu/sites/windrose.phtml?station=AMW \& network=IA_ASOS (accessed 18 December 2021).

Jendritzky, G., Maarouf, A., Staiger, S. (2001). Looking for a Universal Thermal Climate Index UTCI for Outdoor Applications. In Proceedings of the Windsor-Conference on Thermal Standards, Windsor, UK. 
Kołodziej, A. (2021). Krakowskie uczelnie zdecydowały o przedłużeniu nauczania w systemie zdalnym - Uniwersytet Jagielloński i Akademia Górniczo-Hutnicza do 15 maja, uniwersytety Ekonomiczny i Pedagogiczny - do odwołania, Rolniczy - do końca semestru. Polish Press Agency. https://naukawpolsce.pap.pl/aktualnosci/news\%2C81673\%2Ckrakowskie-uczelnieprzedluzyly-zdalne-nauczanie.html (accessed 8 October 2021).

Kowalczyk-Anioł, J., Grochowicz, M., Pawlusiński, R. (2021). How a tourism city responds to COVID-19: A CEE perspective (Kraków Case Study). Sustainability 13, 7914. https://doi.org/10.3 390/su13147914

Lupa, M., Adamek, K., Leśniak, A., Pršek, J. (2020). Application of satellite remote sensing methods in mineral prospecting in Kosovo, area of Selac. Mineral Resour. Manage. 36, 5-22.

Marcinek, M., Piotrowicz, K., Ustrnul, Z. (2016). Characteristics, classification and the range of influence of the halny wind. Wydział Geografii i Geologii, Jagiellonian University. Krakow.

Morawiecki, M. (2021a). Rozporządzenie Rady Ministrów z dnia 11 lutego 2021 r. zmieniające rozporządzenie w sprawie ustanowienia określonych ograniczeń, nakazów i zakazów w związku z wystąpieniem stanu epidemii. Dziennik Ustaw (Journal of Law ) 2021 R. POZ. 267, Warszawa. (in Polish)

Morawiecki, M. (2021b). Rozporządzenie Rady Ministrów z dnia 25 marca 2021 r. zmieniające rozporządzenie w sprawie ustanowienia określonych ograniczeń, nakazów i zakazów w związku z wystąpieniem stanu epidemii. Dziennik Ustaw (Journal of Law ) 2021 R. POZ. 546, Warszawa. (in Polish)

Morawska-Horawska, M., Lewik, P. (2003). Wpływ wysokości i ukształtowania terenu na zróżnicowanie warunków meteorologicznych w Krakowie, in: Lach, J. (Ed.), Dynamika zmian środowiska geograficznego pod wpływem antropopresji. Instytut Geografii Akademii Pedagogicznej w Krakowie, Kraków, pp. 85-94. (in Polish)

Ning, G., Wang, S., Yim, S.H.L., Li, J., Hu, Y., Shang, Z., Wang, J., Wang, J. (2018). Impact of lowpressure systems on winter heavy air pollution in the northwest Sichuan Basin, China. Atmos. Chem. Phys. 18, 13601-13615. https://doi.org/10.5194/acp-18-13601-2018

Nychka, D., Furrer, R., Paige, J., Sain, S. (2021). Fields: Tools for spatial data. In R Package Version 13.3. University Corporation for Atmospheric Research: Boulder USA. https://github.com/ dnychka/fieldsRPackage

Okafor, N.U., Alghorani, Y., Delaney, D.T. (2020). Improving data quality of low-cost loT sensors in environmental monitoring networks using data fusion and machine learning approach. ICT Express. 6, 220-228. https://doi.org/10.1016/j.icte.2020.06.004

OpenStreetMap Contributors (2015). Planet dump from https://planet.osm.org. https://planet. openstreetmap.org (accessed 17 December 2021).

Pedersen, M., Giorgis-Allemand, L., Bernard, C., Aguilera, I., Andersen, A.-M.N., Ballester, F., Beelen, R.M.J., Chatzi, L., Cirach, M., Danileviciute, A., Dedele, A., Eijsden, M. van, Estarlich, M., Fernández-Somoano, A., Fernández, M.F., Forastiere, F., Gehring, U., Grazuleviciene, R., Gruzieva, O., Heude, B., et al. (2013). Ambient air pollution and low birthweight: A European cohort study (ESCAPE). Lancet Respir. Med. 1, 695-704. https://doi.org/10.1016/S22132600(13)70192-9

Peltier, R.E., Castell, N., Clements, A.L., Dye, T., Hüglin, C., Kroll, J.H., Lung, S.C.C., Ning, Z., Parsons, M., Penza, M., Reisen, F., Schneidemesser, E. (2021). An Update on Low-cost Sensors for the Measurement of Atmospheric Composition, December 2020. World Meteorological Organization.

Raaschou-Nielsen, O., Andersen, Z.J., Beelen, R., Samoli, E., Stafoggia, M., Weinmayr, G., Hoffmann, B., Fischer, P., Nieuwenhuijsen, M.J., Brunekreef, B., et al. (2013). Air pollution and lung cancer incidence in 17 European cohorts: Prospective analyses from the European Study of Cohorts for Air Pollution Effects (ESCAPE). Lancet Oncol. 14, 813-822. https://doi.org/10. 1016/S1470-2045(13)70279-1

Raciborski, F., Pinkas, J., Jankowski, M., Sierpiński, R., Zgliczyński, W., Szumowski, Ł., Rakocy, K., Wierzba, W., Gujski, M. (2020). Dynamics of the coronavirus disease 2019 outbreak in Poland: An epidemiological analysis of the first 2 months of the epidemic. Pol. Arch. Intern. Med. 130, 615-621. http://doi:10.20452/pamw.15430

Rogala, B. (2021). Air Quality Index: Kraków wśród miast o najbardziej zanieczyszczonym powietrzu na świecie. https://300gospodarka.pl/live/air-quality-index-wroclaw-warszawakrakow-ranking (accessed 18 December 2021) (in Polish) 
Rolpg, G., Stein, A., Stunder, B. (2017). Real-time Environmental Applications and Display sYstem: READY. Environ. Modell. Software 95, 210-228. https://doi.org/10.1016/j.envsoft.2017.06.025

Rosiek, K. (2017). Pomiary natężenia ruchu kołowego na wlotach do miasta Krakowa ze szczególnym uwzględnieniem ruchu tranzytowego. Report W/I/3035/GK/27/2017 for Krakow City Hall, Krakow. (in Polish)

Rutkowski, J. (1989). Budowa geologiczna regionu Krakowa. Prz. Geol. 37, 302-308. (in Polish)

Schneider, P., Bartonova, A., Castell, N., Dauge, F.R., Gerboles, M., Hagler, G.S.W., Hüglin, C., Jones, R.L., Khan, S., Lewis, A.C., Mijling, B., Müller, M., Penza, M., Spinelle, L., Stacey, B., Vogt, M., Wesseling, J., Williams, R.W. (2019). Toward a unified terminology of processing levels for low-cost air-quality sensors. Environ. Sci. Technol. 53, 8485-8487. https://doi.org/10.1021/ acs.est.9b03950

Serwis Rzeczypospolitej Polskiej (2020). Nowa normalność: etapy znoszenia ograniczeń związanych z COVID-19. https://www.gov.pl/web/koronawirus/nowa-normalnosc-etapy (accessed 08 October 2021). (in Polish)

Serwis Rzeczypospolitej Polskiej (2021). 19 kwietnia otwieramy żłobki i przedszkola, ale przedłużamy obowiązujące obostrzenia do 25 kwietnia. Hotele nieczynne do 3 maja włącznie. https://www.gov.pl/web/koronawirus/Do-25kwietnia-przedluzamy-zasady-bezpieczenstwaz-wyjatkami (accessed 08 October 2021). (in Polish)

Statistics Poland (2021a). About Kraków. https://krakow.stat.gov.pl/dane-o-wojewodztwie/stolicawojewodztwa-926/informacje-o-stolicy-wojewodztwa-1025/ (accessed 17 December 2021).

Statistics Poland (2021b). The impact of the COVID-19 epidemic on selected elements of the labour market in Poland in the second quarter of 2021. https://stat.gov.pl/download/gfx/portalin formacyjny/en/defaultaktualnosci/3407/3/6/1/the_impact_of_the_covid-19_epidemic_on_s elected_elements_of_the_labour_market_in_poland_in_the_second_quarter_of_2021.pdf (accessed 08 October 2021).

Szumowski, Ł. (2020). Rozporządzenie Ministra Zdrowia z dnia 24 marca 2020 r. zmieniające rozporządzenie w sprawie ogłoszenia na obszarze Rzeczypospolitej Polskiej stanu epidemii. Dziennik Ustaw (Journal of Law) 2020 R. POZ. 522, Warszawa. (in Polish)

The Municipal Traffic Engineer Department (2020). Wpływ Stanu Zagrożenia Epidemicznego Na Natężenia Ruchu Drogowego w Krakowie. Department of City Traffic Engineer of Krakow: Krakow, Poland. pp. 1-4.

Thurston, G.D., Kipen, H., Annesi-Maesano, I., Balmes, J., Brook, R.D., Cromar, K., De Matteis, S., Forastiere, F., Forsberg, B., Frampton, M.W., Grigg, J., Heederik, D., Kelly, F.J., Kuenzli, N., Laumbach, R., Peters, A., Rajagopalan, S.T., Rich, D., Ritz, B., Samet, J.M., et al. (2017). A joint ERS/ATS policy statement: What constitutes an adverse health effect of air pollution? An analytical framework. Eur. Respir. J. 49, 1600419. https://doi.org/10.1183/13993003.004192016

Traczyk, P., Gruszecka-Kosowska, A. (2020). The condition of air pollution in Kraków, Poland, in 2005-2020, with health risk assessment. Int. J. Environ. Res. Public Health. 17, 6063. https://doi.org/10.3390/ijerph17176063

Urbanowicz, J., Mlost, A., Binda, A., Dobrzańska, J., Dusza, M., Godzina, P., et al. (2020) Strategia Rozwoju Województwa "Małopolska 2030”. Załącznik do uchwały Nr XXXI/422/20 Sejmiku Województwa Małopolskiego z dnia 17 grudnia 2020 r. https://www.malopolska.pl/_userfiles/ uploads/Rozwoj\%20Regionalny/Strategia\%20Ma\%C5\%82opolska\%202030/2020-12-

17_Zalacznik_Strategia_SWM_2030.pdf (accessed 08 October 2021). (in Polish)

Voivodship Sanitary Inspectorate (2020). Jakość powietrza w Krakowie. Podsumowanie wyników badań. http://krakow.pios.gov.pl/2020/09/24/jakosc-powietrza-w-krakowie-podsumowaniewynikow-badan/ (accessed 18 December 2021). (in Polish)

Wang, W.C.V., Lung, S.C.C., Liu, C.H. (2020). Application of machine learning for the in-field correction of a $\mathrm{PM}_{2.5}$ low-cost sensor network. Sensors. 20, 5002. https://doi.org/10.3390/ s20175002

Wielgosiński, G., Czerwińska, J. (2020). Smog episodes in Poland. Atmosphere 11, 277. https://doi.org/10.3390/atmos11030277

Zaręba, M., Laskownicka, A., Zając, J. (2019). The use of S-guided CREP methodology for advanced seismic structure enhancing processing. Acta Geophys. 67, 1711-1719. https://doi.org/ 10.1007/s11600-019-00314-1 
Zaręba, M., Danek, T., Zając, J. (2020). On including near-surface zone anisotropy for static corrections computation-Polish Carpathians 3D seismic processing case study. Geosciences 10, 66. https://doi.org/10.3390/geosciences10020066

Zhang, L., Cheng, Y., Zhang, Y., He, Y., Gu, Z., Yu, C. (2017). Impact of air humidity fluctuation on the rise of PM mass concentration based on the high-resolution monitoring data. Aerosol Air Qual. Res. 17, 543-552. https://doi.org/10.4209/aaqr.2016.07.0296

Zimmerman, N., Presto, A.A., Kumar, S.P.N., Gu, J., Hauryliuk, A., Robinson, E.S., Robinson, A.L., Subramanian, R. (2018). A machine learning calibration model using random forests to improve sensor performance for lower-cost air quality monitoring. Atmos. Meas. Tech. 11, 291-313. https://doi.org/10.5194/amt-11-291-2018 